DEPARTMENT OF THE INTERIOR

UNITED STATES GEOLOGICAL SURVEY

GEORGE OTIS SMITH, DIRECTOR

BuLLeTIN 601

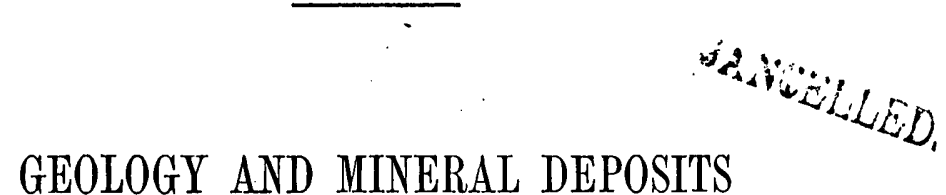

OF THE

\title{
NATIONAL MINING DISTRICT, NEVADA
}

BY

WALDEMAR LINDGREN

WASHINGTON

GOVERNMENT PRINTING OFFIOE

1915 


$$
\begin{aligned}
& 46 \\
& B 9 \\
& \text { nos.601.605 } \\
& \text { Coten }
\end{aligned}
$$

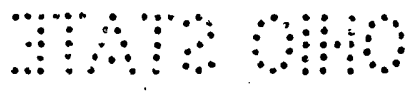

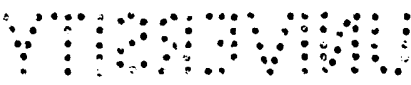




\section{CONTENTS.}

Preface by F. L. Ransome. Page.

Location and field work.......................................... 7

Santa Rosa Range............................................ 7

Topography............................................ 7

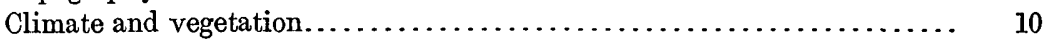

Geology ............................................ 10

Mineral deposits......................................... 12

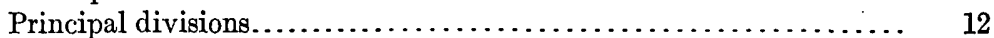

Older mineral deposits................................ $\quad 12$

Tertiary mineral deposits.............................. 14

Metal production of Santa Rosa Range....................... 16

Literature of Santa Rosa Range................................ 17

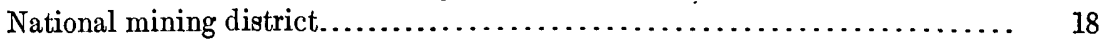

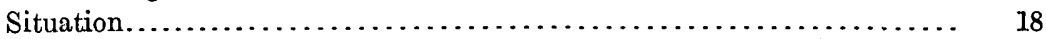

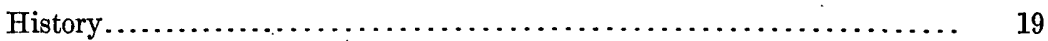

Prospecting and mining..................................... 19

Leasing............................................... 20

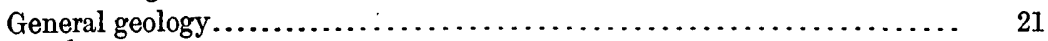

The rocks................................................ 23

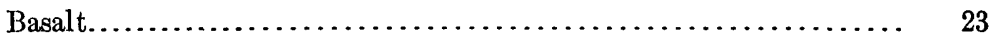

Distribution..................................... 23

Petrography........................................ 23

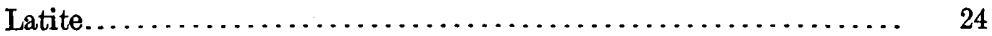

Distribution..................................... 24

General petrography............................... $\quad 25$

Rocks from Round Hill............................. $\quad 26$

Rocks from National mine........................... $\quad 26$

Relations and age.................................... $\quad 27$

Trachyte............................................. 27

Rhyolite............................................. 28

Mineral deposits.............................................. 30

General character................................... 30

Gold shoot of the National mine.......................... 32

Genesis of the veins..................................... 32

Detailed descriptions................................... 33

National mine.................................... $\quad 33$

Development and equipment...................... 33

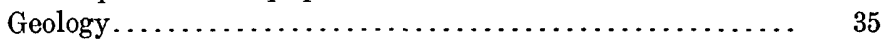

Alteration of country rock....................... 36

The vein..................................... 36

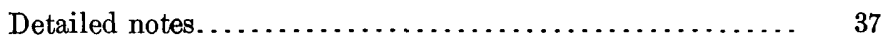

Ore shoot.......................................... 38

Late movements................................. 42

Ore........................................... 42

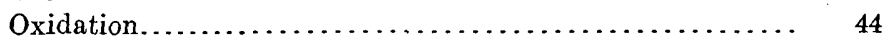

Secondary sulphides........................... 44 
National mining district-Continued.

Mineral deposits-Continued.

Detailed descriptions-Continued.

National Mammoth Mining Co........................ ${ }_{45}^{4}$

Radiator Hill................................ 46

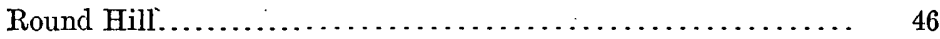

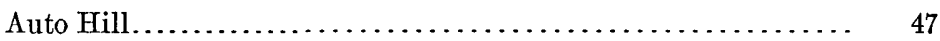

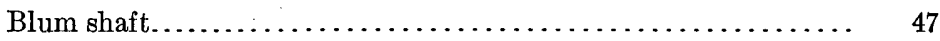

Edmunds tunnel................................ 48

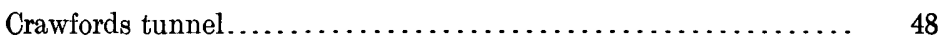

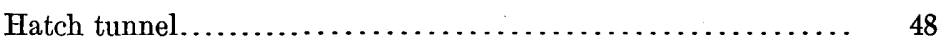

Hyde tunnel........................................ 48

Developments south of Stall shaft................... 49

Indian Valley tunnel............................ 49

Prospects on Buckskin Peak....................... $\quad 50$

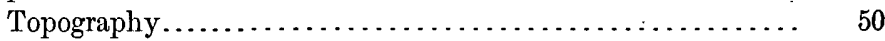

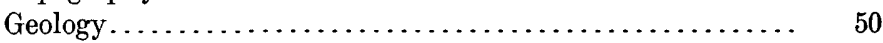

Veins and prospects................................. 50

Summit of Buckskin Mountain................... 50

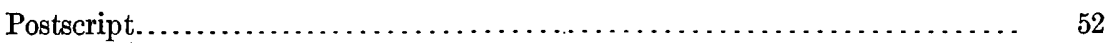

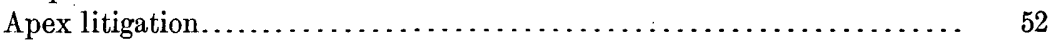

Comments on statements elicited by suit....................... 55

Index

\section{ILLUSTRATIONS.}

Prate I. Geologic map of the National district

II. $A$, General view of National, Nev., looking east; $B$, Buckskin Peak, looking southeast....................................

III. $A$, West slope of range north of Eightmile Creek; $B$, Basalt flows north

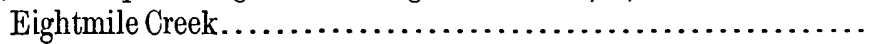

IV. $A$, Charleston Hill and National mine, looking southeast; $B$, View looking north from Stall shaft across Eightmile Creek...........

V. Map of National mine....................................

VI. $A$, Gold quartz from National mine; $B$, Stibnite vein, Radiator Hill.

VII. $A$, Gold quartz from National mine; $B$, Same, showing dendritic

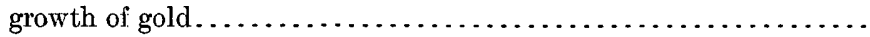

VIII. Photomicrographs of gold quartz from National mine............

Frgure 1. Index_map of northwestern Nevada........................

2. Outline map of Santa Rosa Range, Paradise quadrangle...........

3. Diagrammatic section showing geologic features of National mining

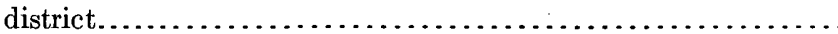

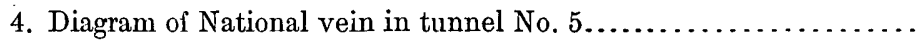

5. Diagram of National vein in small stope just above tunnel No. 5....

6. Diagram of quartz seam in National vein in high-grade stopes between levels 4 and $4 \frac{1}{2}$.

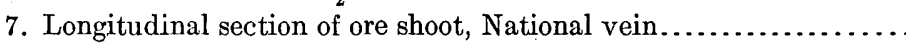

8. Cross section of National vein along Stall shaft................. 


\title{
PREFACE.
}

\author{
By F. L. Ransome.
}

The geologic work done in Nevada by the Geological Survey during the last few years is of four general kinds, which, however, are not sharply separable. These are (1) comprehensive, detailed studies of important mining districts, exemplified by the work of Spurr at Tonopah, ${ }^{1}$ Ransome at Goldfield, ${ }^{2}$ Spencer at Ely, ${ }^{3}$ and Knopf at Yerington; ${ }^{4}(2)$ less complete reports on minor or comparatively undeveloped districts, such as that of Spurr on Silver Peak, ${ }^{5}$ of Ransome, Emmons, and Garrey on Bullfrog, ${ }^{8}$ and of Schrader on Jarbidge, Contact, and Elk Mountain, ${ }^{7}$ on Rochester, ${ }^{8}$ and on the mining districts of the Carson Sink quadrangle (Rawhide, Wonder, Fairview, etc.) ; (3) economic reconnaissance of mining districts with incidental general geology, such as that of Emmons in northern Nevada, ${ }^{10}$ of Ransome in Humboldt County, ${ }^{11}$ and of Hill in northwestern ${ }^{12}$ and eastern ${ }^{13} \mathrm{Nevada}$; (4) general reconnaissance, exemplified by the work of Spurr ${ }^{14}$ and Ball. ${ }^{15}$

In addition to the reports mentioned a number of brief accounts of mining districts, prepared incidentally in connection with other investigations, have appeared in several bulletins, especially in the annual volumes devoted to short contributions in economic geology.

1 Spurr, J. E., Geology of the Tonopah mining district, Nev.: U. S. Geol. Survey Prof. Paper 42, 1905.

2 Ransome, F.L., The geology and ore deposits of Goldfield, Nev.: U. S. Geol. Survey Prof. Paper 66, 1909.

${ }^{8}$ Spencer, A. C., report in preparation.

1 Knopi, Adolph, report in preparation.

5 Spurr, J. E., Ore deposits of the Silver Peak quadrangle, Nev.: U. S. Geol. Survey Prof. Paper 55, 1906. .

- Ransome, F. L., Emmons, W. H., and Garrey, G. H., Geology and ore deposits of the Bullirog district, Nev.: U.S. Geol. Survey Bull. 407, 1910.

Schrader, F. C., A reconnaissance of the Jarbidge, Contact, and Elk Mountain mining districts, Elko County, Nev.: U. S. Geol. Survey Bull. 497, 1912.

8 Schrader, F. C., The Rochester mining district, Nev.: U. S. Geol. Survey Bull. 580, pp. 325-372,1915.

${ }^{9}$ Schrader, F. C., report in preparation.

${ }^{10}$ Emmons, W. H., $\Lambda$ reconnaissance of some mining camps in Elko, Lander, and Eureka counties, Nev.: U. S. Geol. Survey Bull. 408, 1910.

11 Ransome, F. L., Notes on some mining districts in Humboldt County, Nev.: U. S. Geol. Survey. Bull. 414, 1909.

12 Hill, J. M., Some mining districts of northeastern California and northwestern Nevada: U. S. Geol. Survey Bull. 594, 1915.

13 Hill, J. M., report in preparation.

14 Spurr, J. E., Descriptive geology of Nevada south of the fortieth parallel and adjacent portions of California: U. S. Geol. Survey Bull. 208, 1903.

15 Ball, S. H., A geologic reconnaissance in southwestern Nevada and eastern California: U.S. Geol. Survey Bull. 308, 1907. 
As a result of the foregoing work a good deal has been learned of the local geologic conditions in the mining districts in Nevada, although little has yet been done to interpret the general geology of the State with the accuracy and detail required for the folios of the Geologic Atlas of the United States.

The reconnaissance work of Hill on the west, Ransome on the south, and Emmons on the east left unexamined an extensive region in northern Humboldt County. Within this rather inaccessible country, in large part tributary to Quinn River and containing the forbidding Black Rock Desert; are a few scattered mining districts of whose geologic features -little is generally known. The present report, which probably belongs in the second of the four classes into which the official geologic reports on Nevada have been divided, helps to supply this deficiency.

Special interest attaches to the description of the extraordinary shoot of rich gold ore which brought the district into prominence in 1909 and to the conclusion that the high-grade ores of National, like those of Goldfield, were deposited within a comparatively short distance from the surface. Ascending hot-water connected with volcanism is believed to have been the active agent of deposition in each place, although at National descending water appears to have played no such part in the original deposition of the ores as that which has been suggested in explanation of the unique alunitic deposits at Goldfield. The study of the National ores has afforded another example of the frequent association in Nevada of cinnabar and of some antimony mineral with rich gold or silver ore, although in this district, as Mr. Lindgren shows, the veins that carry much stibnite are not themselves rich in gold or silver. In their general geologic relations and in their mineralogic character the ore deposits of National appear to be more closely related to those of the Seven Troughs district ${ }^{1}$ than to any others known in Nevada.

\footnotetext{
1 Ransome, F. L., Notes on some mining districts in Humboldt Connty, Nev.: U. S. Geol. Survey
} Bull. 414, pp. 14-25, 1909 . 


\title{
GEOLOGY AND MINERAL DEPOSITS OF THE NATIONAL MINING DISTRICT, NEVADA.
}

\author{
By Waldemar Lindgren.
}

\section{LOCATION AND FIELD WORK.}

The National mining district is in Humboldt County, Nev., near the Oregon State line. (See fig. 1.) It lies on the western slope of the Santa Rosa Range, facing the broad valley of Quinn River, and is included within the Santa Rosa National Forest. The mining camp, National, is connected by stage and automobile service with Winnemucca, 70 miles to the south, by a road that skirts the western foot of the range for 35 miles and then crosses it in a southeastern course through a gap at Flynn station. (See fig. 2.)

No large production of precious metals had been recorded from this region up to 1908 , but in that year a bonanza shoot of gold quartz was discovered which within four years yielded about $\$ 4,000,000$. This shoot is, in fact, one of the most remarkable and interesting bodies of high-grade ore discovered in the West.

The district was examined between June 9 and June 22, 1911, and was revisited in August of the same year, when a few days were devoted also to a study of the Buckskin and other adjacent districts.

Owing to a protracted lawsuit over the ownership of a part of the National vein (see pp. 52-54), which began about the time of the visit, it was deemed unwise to publish the material at once, but a brief summary of the geologic structure of the district was printed in August, 1911, in the National Miner, a local paper.

\section{SANTA ROSA RANGE.}

TOPOGRAPHY.

The Santa Rosa Range (see fig. 2), a narrow desert mountain range typical of north-central Nevada, extends from Winnemucca, the old town on Humboldt River, to a point a few miles north of the Oregon State line, a distance of about 70 miles, in a direction a few degrees east of north. The whole range is shown on the United States Geological Survey's reconnaissance sheet of the Paradise quadrangle, which lies between $41^{\circ}$ and $42^{\circ}$ north latitude and $117^{\circ}$ and $118^{\circ}$ west longitude. 
The south end of the range is marked by Winnemucca Mountain, which reachès an elevation of about 6,700 feet above sea level. The first foothills rise from the bank of Humboldt River (elevation 4,300 feet), and for 7 or 8 miles north of Winnemucca Mountain, to Bloody

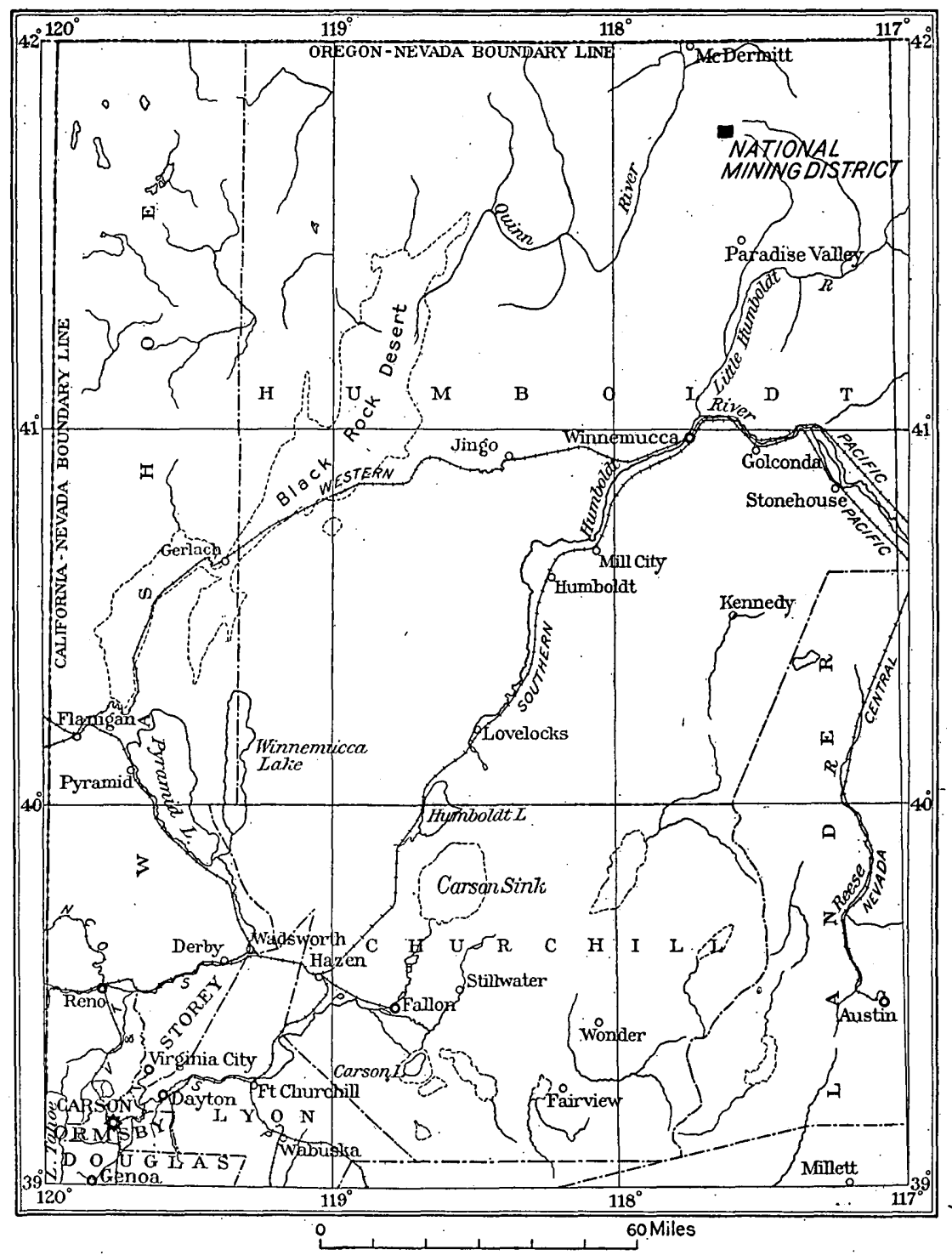

Figure 1.-Index map of northwestern Nevada.

Run Peak, the range is only 2 miles wide, reaching elevations below 6,500 feet.

In the next 15 miles northward from Bloody Run Peak (elevation 7,700 feet) the range widens. Beyond a gap at which the range is 
offset a few miles toward the east it continues due north for 20 miles with a width of 6 to 10 miles, and in Rose Mountain and Spring Peak reaches elevations of 9,600 and 9,400 feet. North of Spring Peak the

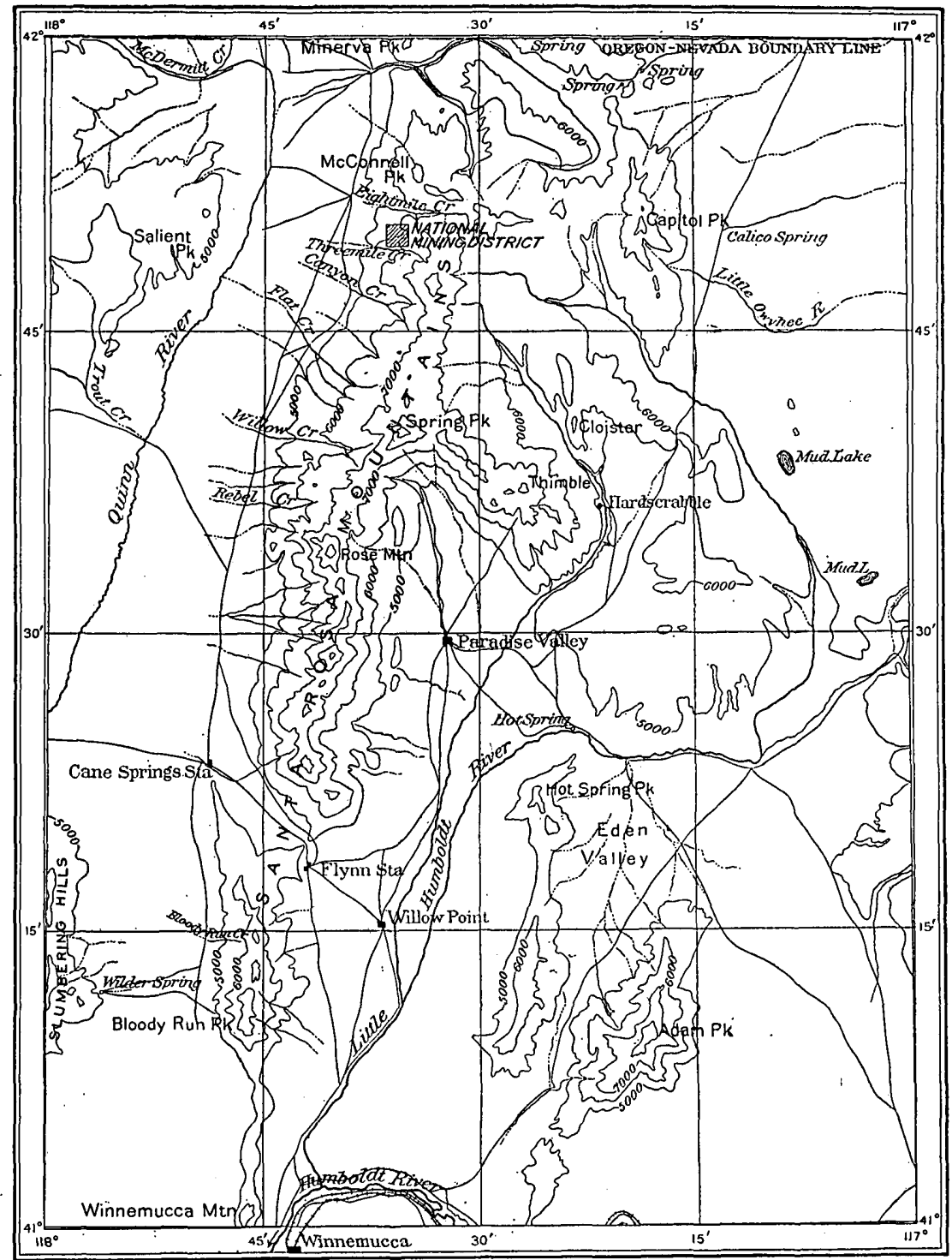

\begin{tabular}{lllllllllll}
0 & 2 & 4 & 6 & 8 & 10 & 12 & $14^{\circ}$ & 16 & 18 & 30 \\
\hline
\end{tabular}

Contour interval 1000 feet

Figure 2.-Outline map of Santa Rosa Range, Paradise quadrangle.

western front continues to the Oregon line, its appearance being similar to that of the western front in the southern part of the range. The eastern slope, on the other hand, widens by salients and plateau-like ridges, which express the geologic structure of the eastward-dipping 
lava flows of this end of the range. The highest point in this part of the range is Buckskin Peak, which has an elevation of 8,800 feet. At the Oregon State line the range is only 6 miles wide and soon sinks to the lava plateau.

The range is drained on its west side to Quinn River, which flows in a sagebrush-covered valley 6 to 10 miles wide. Here gently sloping débris fans lead down from the foothills. There is flowing water in Quinn River, derived mainly from tributaries that come from the Santa Rosa Range, and it serves for some irrigation, but it sinks ultimately into the sand of the basins north of Winnemucca and Pyramid Lakes. Opposite National the river flows at an elevation of only 4,200 feet.

The eastern base of the Santa Rosa Range lies 600 to 1,600 feet higher than its western base. It is drained by Little Humboldt River and, toward the northeast, by the headwaters of the Little Owyhee, which empties into Snake River near the boundary of Idaho and Oregon. The map forming figure 2 shows well how at its northern end the range changes to a plateau having an elevation of 6,000 feet, heavily scored by erosion from the west side.

\section{CLIMÁTE AND VEGETATION.}

The climate at Winnemucca is that characteristic of the lower parts of the Great Basin, the summers being hot and dry and the winters cold but pleasant, with little precipitation. Toward the north end of the range the climate is much colder, and at an elevation of 6,000 feet, as at the National camp, the winters are long and the snow is deep. In the beginning of June, 1911, heavy snowdrifts were lying on the higher ridges about National, and the big cirques of Spring Peak were filled with snow.

To the casual observer this range appears absolutely devoid of arboreal vegetation, but this impression is not quite correct. A few willows along the streams and creeks contrast pleasingly with the dull brown of the rock, and in the gulches and cirques of the higher range as many as 50 trees may be counted to a square mile. There is a heavy grow th of sagebrush in the valley and on the smoother foothills. The streams on the west side of the range and also the one that flows southward from Spring Peak serve to irrigate small ranches at the foot of the range, and these green alfalfa fields delight the eye of the tired desert traveler.

\section{GEOLOGX.}

Geologically the Santa Rosa Range is really a "terra incognita." The maps of the Fortieth Parallel Survey extended only as far north as Winnemucca, at latitude $41^{\circ}$. The outcrops on the north side of the 


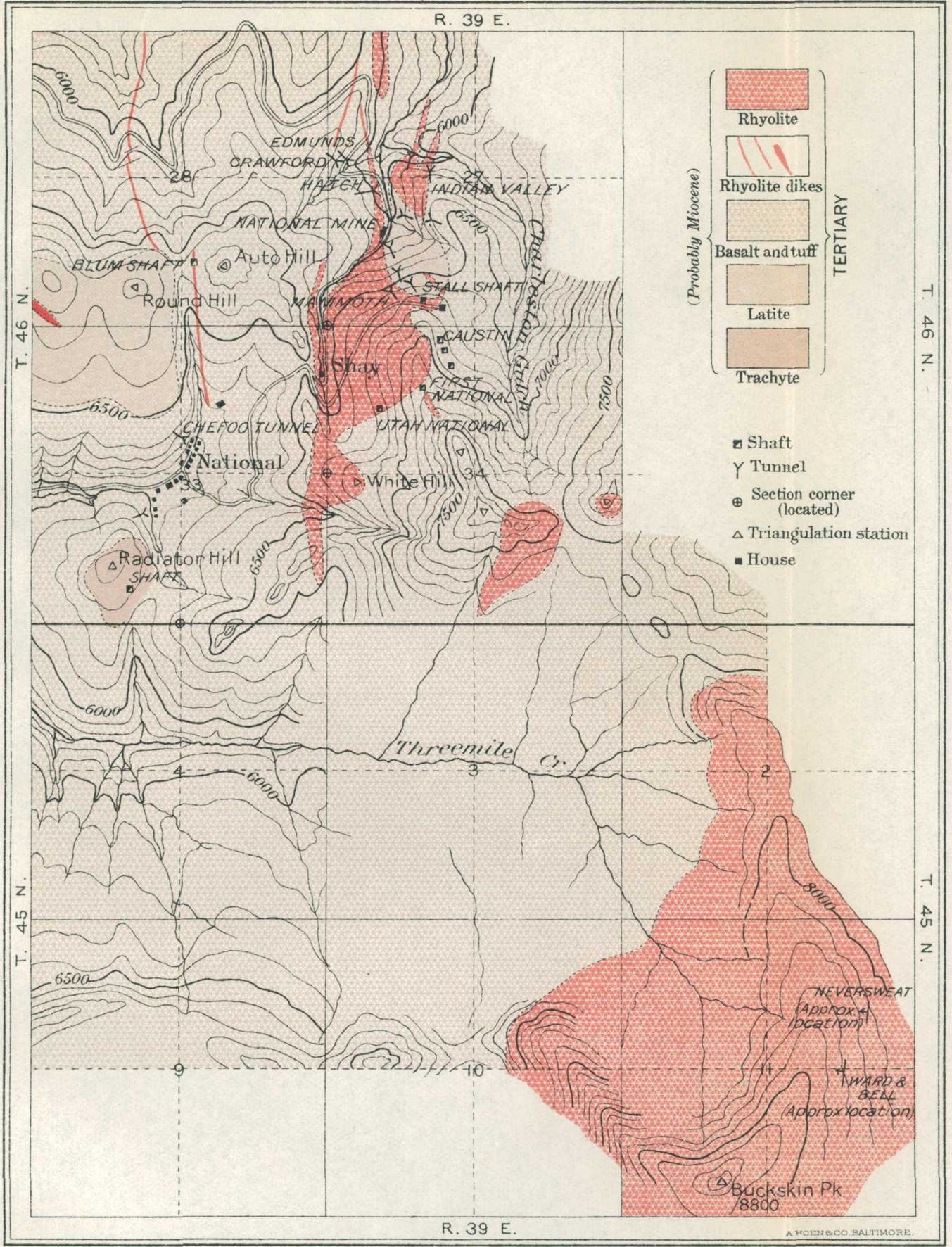

SKETCH MAP OF NATIONAL MINING DISTRICT, HUMBOLDT COUNTY, NEVADA

Topography and geology by Waldemar Lindgren

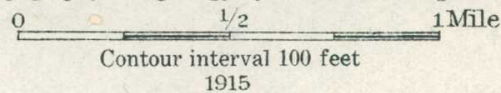


river close to Winnemucca are, on these maps, indicated as "Jurassic (?)."

Considered geologically the range may be divided into two parts. (See Pl. I.) The northern and northeastern parts consist of Tertiary basalt, in many flows, one superimposed upon another, after the manner of the Miocene Columbia River basalt, with which these flows should, in fact, be correlated. A few flows of rhyolite are intercalated in the flows of basalt, which is also intersected by dikes of rhyolite. Flows of latite and trachyte form minor parts of the series.

This Tertiary part of the range begins abruptly just north of Canyon Creek, where the basalts lie on lustrous clay slates. North of this point no older rocks are seen. The contact runs southeastward from the head of Canyon Creek, and probably the whole northeastern part of the range northeast of Spring Peak and Thimble Peak is built up mainly of basalt. The flows as a whole dip northeastward at angles ranging from $8^{\circ}$ to $15^{\circ}$. A certain dependence of topography on geology is manifest in this part of the range. Although the western slope is rough and steep, the eastern side tends to form a dissected plateau, sloping gently from the summit; for instance, at the head of Eightmile Creek and at the State line, as noted above, the range has changed into a plateau with a western scarp.

Lava flows are seen again on the west side of Quinn River valley, in the steep slope of Salient Creek. The persistent northeasterly dip of the lavas indicates doming, and it is probable that the upper part of the Quinn River valley in the latitude of National represents a sunken slice of this dome. It is difficult to interpret the structure of this northern part of the range without assuming doming and faulting, although the western slope of the range now shows no topographic indications of a fault.

The southern and larger end of the range is free from volcanic rocks except a few small basaltic flows close to the Humboldt River near Winnemucca. The narrow ridge is topographically symmetrical down to the line where the older rocks are covered by the wash, and there are no topographic indications of faulting.

The range is built up of clay slates, calcareous slates, and some limestone. These sedimentary rocks trend north, parallel to the range, and are strongly folded and compressed.

At the south end of Winnemucca Mountain, at the Pride of the West mine, there are calcareous slates, in part metamorphosed to hornfels, with strata of gray limestone. On the west side of the mountain there are clay slates of varying strike and dip. A very similar series of rocks occupies the larger part of the southern range as far north as Flynn station. 
Well-preserved fossils found at the Pride of the West mine were identified by T. W. Stanton as Pseudomonotis subcircularis Gabb, which is characteristic of the Upper Triassic. There is little doubt that the greater part of the sedimentary rocks of the range are of Triassic age. No intercalated Triassic lavas similar to those of the Humboldt Range were observed.

Lustrous clay slates form the most common "float" along the western foot of the range. Along Canyon Creek a few miles south of National the smooth clay slates strike north and dip $50^{\circ}-80^{\circ} \mathrm{E}$.

The sedimentary rocks are intruded and metamorphosed by at least five stocks of granodiorite or quartz monzonite, all of which are probably of post-Triassic age.

A small mass of intrusive diorite occurs on Winnemucca Mountain and is especially conspicuous on its steep eastern slope. A second much larger intrusive mass lies near Bloody Run Peak. A third mass is found in the southern part of the range north of Flynn station. A fourth and fifth stock lie near Rebel Creek and on Spring Mountain. None of these stocks was investigated in detail.

\section{MINERAI DEPOSITS.}

\section{PRINCIPAL DIVISIONS.}

The mineral deposits of the Santa Rosa Range, like those of so many other parts of Nevada, may be divided into two principal classes-(1) gold and silver bearing veins that occur in or near the Tertiary volcanic rocks and that are of Tertiary or possibly in part of Quaternary age; (2) gold and silver bearing veins that occur in the sedimentary rocks and in the post-Triassic granular rocks intruded into the sediments and that are probably of late Mesozoic age.

\section{OLDER MINERAL DEPOSITS.}

Though little work was done on the deposits that antedate the Tertiary lavas, a few notes may be given as to their general character. Such deposits are widely distributed through the older rocks of the range from Winnemucca Mountain to Canyon Creek, but the only places from which a large production has been reported is the Spring City camp, north of Paradise.

The deposits are quartz veins or, more rarely, replacement deposits in limestone or lime shale. The quartz is generally milky white and massive, not drusy, and in appearance is similar to that of the gold quartz veins of California. These veins carry both silver and gold, though the value of the gold usually exceeds that of the silver. Some of them have yielded placers which were worked at a profit.

There is little doubt that these deposits owe their origin to mineralization that followed the intrusion of granular rocks. The appearance 
of samples of the ore examined suggests that the deposits were formed at intermediate depths and that they have been subjected to great pre-Tertiary erosion.

In the southern foothills of Winnemucca Mountain, at an elevation of 4,400 feet, the Pride of the Mountain vein was worked as early as 1868 for lead, silver, and gold. According to the data contained in "Raymond's Reports"' the mine was worked between 1868 and 1877. The ores were first shipped to San Francisco but were later treated by stamping and roasting and by amalgamation in the Humboldt Reduction Works at Winnemucca. The ore is said to have had a value of $\$ 40$ to $\$ 100$ a ton. Several other veins in the vicinity are mentioned but were evidently not worked extensively, as no figures showing production are given. The deposit is said to be a vein with northwest strike and northeast dip. The country rock is calcareous Triassic shale.

On the west side of the mountain, at an elevation of about 5,975 feet, is the Adamson gold deposit, described on page 15. This is evidently a deposit of late Tertiary or Quaternary age. On the east side of the mountain, along a small intrusive body of diorite, there are several copper deposits containing oxidized ore, probably of contact-metamorphic origin and clearly belonging to the earlier series.

In the middle part of the Santa Rosa Range is the old camp of Spring City, 8 miles northwest of the town of Paradise. The district was discovered about 1868 and organized in 1873, and its mines were worked most actively in the early eighties. ${ }^{2}$ It is reported to have produced metals to the value of several million dollars. The last important work was done in 1891, though in the last two years a few tons of ore have been shipped, and some tailings were cyanided in 1911 and 1912.

According to information obtained from Mr. R. S. Bolam, the formation consists of calcareous slate cut by dikes of porphyry which are said to be older than the deposits. East of this, according to report, there is a great rhyolite flow. There was a shallow oxidized zone containing chloride of silver, and below this some pyrite, ruby silver, and argentite were found. In depth zinc blende increased and the ore was of low grade. The ore contained both gold and silver and yielded from $\$ 8$ to $\$ 20$ in gold and $\$ 10$ to $\$ 1,000$ in silver per ton. Where barren the veins are wide and prominent, but where ore occurred they are narrow. There are two systems of veins, the first called the Paradise and the second the Bullion-Wildgoose. One stope in the Bullion-Wildgoose vein is reported to be 300 feet long, 300 feet high, and in places as much as 20 feet wide. The work was carried

\footnotetext{
1 Raymond, R. W., Statistics of mines and mining in the States and Territories west of the Rocky Mountains.

2 Burchard, H. C., Rept. Director of the Mint on the production of precious metals in 1883, pp. 515-529; also for 1884, p. 357 .
} 
on mainly by tunnels, which reached depths of 600 to 700 feet below the outcrops. The proportion of gold to silver is said to have been greater at depth than near the surface.

Not having examined these deposits, I do not feel entirely certain that they were formed during the older period of mineralization.

On the west side of the range prospecting has been carried on at Rebel, ${ }^{1}$ Willow, and Canyon creeks, the last only a few miles south of National. All these deposits are of the older series and are generally in slates.

Some prospecting was done on Rebel Creek in 1911. The Ohio claim is one of the earliest locations on the creek. This prospect was worked in 1884, according to the reports of the Director of the Mint. The veins of Canyon Creek lie in slate and are about parallel to the schistosity. They contain milky quartz, some siderite, and a little pyrite. The developments are insignificant.

On Pole Creek, about a mile south of the upper part of Canyon Creek, much gold quartz float was found in the early days and a 5 -stamp mill was erected to treat it. The production was $\$ 30,000$, it is said. No vein was found.

Placer deposits that probably derived their gold from these preTertiary veins were formerly worked on a small scale at the foot of the range on Willow Creek, about due east of Spring Peak.

\section{TERTIARY MINERAL DEPOSITS.}

During the early prospecting the deposits in the Tertiary lavas of the north end of the range appear to have been overlooked, though it is said that the reins on Buckskin Peak were known many years before the deposits of the National district were discovered. These deposits, found in 1907, will be described in detail in the following pages and are therefore only briefly referred to here. They are fissure veins, most of them narrow and of low grade, carrying a little gold and a few ounces of silver. They contain, in a drusy, fine-grained quartz gangue, small amounts of pyrite, zinc blende, and other minerals, but all carry stibnite in larger or smaller amounts, and at least one deposit carries cinnabar. In one of these veins was found the remarkable shoot of pale gold (electrum) which within four years yielded nearly $\$ 4,000,000$. The veins northward have a steep westerly dip and occur in rhyolite, basalt, and latite. There are no placers.

The lavas in which the veins occur are probably of Miocene age and the veins were doubtless formed by the action of ephemeral hot springs after the extrusion of a large sheet of rhyolite late in the period of volcanic activity.

1 Burchard, H. C., Rept. Director of the Mint on production of precious metals in 1884, p. 357, 1885, 
On the western slope of Winnemucca Mountain, at an elevation of 6,000 feet, a remarkable deposit, which deserves special mention, was worked by W. G. Adamson in 1911. The rocks exposed on the western slope are dark, smooth, fissile slates, slightly altered by contact metamorphism, but they include also some calcareous slates. The general strike is northward, but the dip is very irregular. A mass of intrusive diorite is exposed on the east side of Winnemucca Mountain, its contact with the slates being near the top of the ridge on that side. The slates are cut by a few dikes of porphyry, which is probably related to the diorite.

There are several prospects in this vicinity, and some of them, about 150 feet higher up than Adamson's camp, contain calcite veins cementing irregular brecciated zones. These remind one strongly of hot-spring deposits formed near the surface. The veinlets are banded and drusy, the slates between them soft and yellowish.

At Adamson's camp a well-defined vein outcrops, striking northeast and dipping steeply northwest. It is traceable for a few hundred feet. The vein filling, which is several feet wide, consists of granular calcite distinctly banded and stained yellow by limonite. At the outcrop back of the mine office it contains rather plentiful specks of cinnabar. In composition, appearance, and structure the vein recalls strongly a hot-spring deposit. An assay by Prof. E. E. Bugbee gave a trace of gold and one-third of an ounce of silver to the ton.

The northeastern part of the vein beyond the mine office appears to be faulted to the southeast with an offset of about 200 feet. The discovery in this part is an outcrop consisting mainly of brecciated slate filled with drusy quartz. This quartz vein is probably the continuation of the calcite vein. A tunnel 30 feet below the top of the outcrop disclosed a well-defined vein 10 feet wide, striking northeast and dipping $60^{\circ} \mathrm{NW}$. A narrow and persistent streak along the footwall contains barite with quartz. Rich ore with pale native gold was struck in the tunnel near the floor and is contained in a narrow streak which, with clay and limonite, also lies along the footwall. The rich ore did not extend to the roof of the tunnel, but within a short space coarse gold was extracted to a value of $\$ 8,000$. This was in 1911. The developments since then have been continued and a small mill has been erected. The statements in the reports on the metal production of Nevada in the Survey's "Mineral Resources of the United States" do not indicate that any large ore shoot has yet been encountered.

The high-grade ore continued below the tunnel level and was taken out by underhand stoping. In some places the gold formed an almost continuous sheet along the footwall. At other places the pay shoot widened and contained ore of milling grade. A small pan mill was 79102 - Bull. $601-15-2$ 
installed in 1911, the same pan in which the first high-grade ore from the National mine was milled.

The rich ore, when examined closely, is seen to consist of finegrained drusy quartz in which the gold is contained in closely massed rodlike or clublike forms, with a tendency to dendritic development, not greatly different from the mode of occurrence at the National mine.

A tunnel 50 feet below the upper tunnel did not cut the vein, but ran into what seems to be an east-west cross fracture faulting the vein. This vein also contained some quartz and a little gold. Very likely, however, this cross fracture antedates the mineralization. There is a marked difference between the calcite-cinnabar filling in the southwestern part of the vein and the quartz-barite-gold filling in the northeastern part, so that these different parts may have been filled during successive stages of the mineralization. That the whole mineralization at this place is due to the action of hot springs at points very close to the surface can scarcely be doubted.

There are no volcanic rocks in the immediate vicinity, but there are several basalt flows near Winnemucca, and hot springs breaik out along Little Humboldt River, above that town.

\section{METAL PRODUCTION OF SANTA ROSA RANGE.}

Accurate statistics are unfortunately not obtainable regarding the production of the mining districts of the Santa Rosa Range. The production of Humboldt County given in the later reports of the United States Mint and the United States Geological Survey conveys little information, because the usually heary output of the districts of the Humboldt Range forms part of it. The production falls in three well-defined periods, corresponding to the development of three districts.

The earliest period, from 1868 to 1880, corresponds with the working of the Pride of the Mountain mine, in the Winnemucca district. This mine may have yielded $\$ 1,000,000$, but this figure is based upon no accurate data.

The next period, from 1880 to 1891, corresponds to the working of the rich veins of the Paradise district, and this production is said by local authorities to have amounted to several million dollars. No accurate data of total production are available. According to the report of the Director of the Mint for 1883, the Bullion mine produced in that year about $\$ 400,000$ in silver and gold. From January, 1879 , to December, 1883, the Paradise Valley Mining Co. produced $\$ 366,735$. From August to December, 1883, the production of this company was $\$ 72,733$ in silver and $\$ 9,260$ in gold. In 1884 , according to the same authority, the production of the Paradise Valley 
Mining Co. was $\$ 215,259$. In 1887 the same production was $\$ 126,000$; in $1888, \$ 16,963$; in $1889, \$ 40,054$; in $1890, \$ 9,264$. If these scattered figures give any indication of the real production, the total output has probably not exceeded $\$ 3,000,000$. Operations ceased in 1891. Since 1911 the reports of the United States Geological Survey indicate an awakening from the dormant stage. A production of $\$ 2,313$ was recorded in 1912 . The production from the Rebel Creek and Willow Creek districts is not known; the former has yielded a little gold and silver ore, and placers were worked in the latter.

The last period of metal yield in the Santa Rosa Range began in 1909 with the discovery of the National bonanza in the hitherto unproductive northern part of the range. Unfortunately, though the production of Humboldt County is known, no figures showing the output of this mine separately could be given in the statistics collected by the United States Geological Survey because of the rule against disclosing individual production. From the data given in the Survey's "Mineral resources of the United States" from 1910 to 1913 and from some hints vouchsafed in the text it may be inferred that the production of the National vein was at least $\$ 80,000$ in 1909 , $\$ 1,000,000$ in $1910, \$ 500,000$ in 1911 , and $\$ 600,000$ in 1912 . This would amount to $\$ 2,180,000$, but there are reasons for believing that this is fully $\$ 500,000$ short of the actual production. On the other hand, it has been stated that the production to November, 1910, was $\$ 1,700,000$, and the current reports in the district assign a production of about $\$ 3,000,000$ or $\$ 4,000,000$ to the mine up to the end of 1912 . Certain it is that during the whole period of working more or less ore stealing went on, and it is stated that the value of the ore stolen before the present company took hold of the property amounted to many hundred thousand dollars.

The lotal production of the mining districts in the Santa Rosa Range since 1869 is thus probably not less than $\$ 7,000,000$.

\section{LITERATURE OF SANTA ROSA RANGE.}

The literature on the Santa Rosa Range and the National mining district is scant. The following list is probably complete:

1870. Raymond, R. W., Statistics of mines and mining in the States and Territories west of the Rocky Mountains [for 1869], p. 193.

Describes Pride of the Mountain vein, on Winnemucca Mountain.

1877. Hague, Arnold, West Humboldt region: U. S. Geol. Expl. 40th Par., vol. 2, pp. 737-738, 1877.

Describes limestone, slate, and sandstone of Winnemucca Mountain; also diorite and syenite.

1883. Burchard, H. C., Report of the Director of the Mint on the production of gold and silver in 1883, pp. 525-529, Washington, 1884.

Contains brief descriptions of several mines in the Santa Rosa Range. 
1884. Burchard, H. C., Report of the Director of the Mint on the production of gold and silver in 1884, p. 357 , Washington, 1885.

Contains brief descriptions of several mines in the Santa Rosa Range.

1905-1913. U. S. Geological Survey Mineral Resources of the United States.

Centains statistical data of production from National, Winnemucca, and other districtsin the Santa Rosa Range, with excerpts from geologic reports, particularly 1911, p.517; 1912, p. 679; and 1913, p. 797; all in pt.1.

1910. Cutler, H. C., National, Nevada: Min. and Sci. Press, Nov. 5, 1910, p. 607.

Firstdescription of geology and ores of the National district.

1911. Iindgren, Waldemar, National miner, Aug. 18, 1911; Min. and Eng. World, Dec. 9, 1911, p. 1175-1176.

1912. Lindgren, Waldemar, The bonanza of National, Nev.: Washington Acad. Sci. Jour., vol. 2, No. 4, Feb. 19, 1912.

Brief description of the salient points of geologic features.

1912. Winchell, A. N., Geology of the National district: Min. and Sci. Press, Nov. 23, 1912, p. 658.

A more detailed description than any previously published of the geologic features and vein phenomena of the National district. Gives elaborate succession of volcanic flows.

1912. U. S. Circuit Court, Nevada. National Mines Company $v$. Charleston Hill National Mines Syndicate and the Mammoth Mines Company.

Testimony of H. V. Winchell, A. C. Lawson, and others bearing upon the geologic conditions near the National vein, $2,700 \mathrm{pp}$.

\section{NATIONAL MINING DISTRICT.}

\section{SITUATION.}

The National mining district is in northern Nevada, on the western slope of the Santa Rosa Range, in T. 46 N., R. 39 E., secs. 27, 28, 33, and 34 . The traveler from the south can reach the district by following the road that skirts the western base of the range for 40 miles and then, at McConnell's ranch, a bright spot of alfalfa on the dreary sagebrush plains, taking a road that ascends the gentle slope of Threemile Creek, a little stream that comes mainly from the cirques of Buckskin Peak. (See Pl. II, B, and fig. 2, p. 9.) About 2 miles up the creek from McConnell's this road turns with steeper grade up the canyon of a small tributary of Threemile Creek coming from the north. At the basin-like head of this canyon is the town of National, which stands 1,300 feet above the base of the range and about 6,100 feet above sea level. (See PI. II.)

The panorama seen from any of the hills or ridges around this basin is interesting and striking. The mining camp of National, a typical Nevada boom town, straggles for half a mile along the bottom of the smooth basin. In June, 1911, the town consisted of 50 frame houses and about 100 tents, the National Hotel, a two-story frame structure, being the most striking object. No trees shade the hills, but, as seen on a June day, the gray-green mantle of the luxuriant sagebrush and the broad splashes of yellow wild flowers, against the dark reddish-brown background of the basalt flows of the high ridges, give the color scheme of the landscape. 


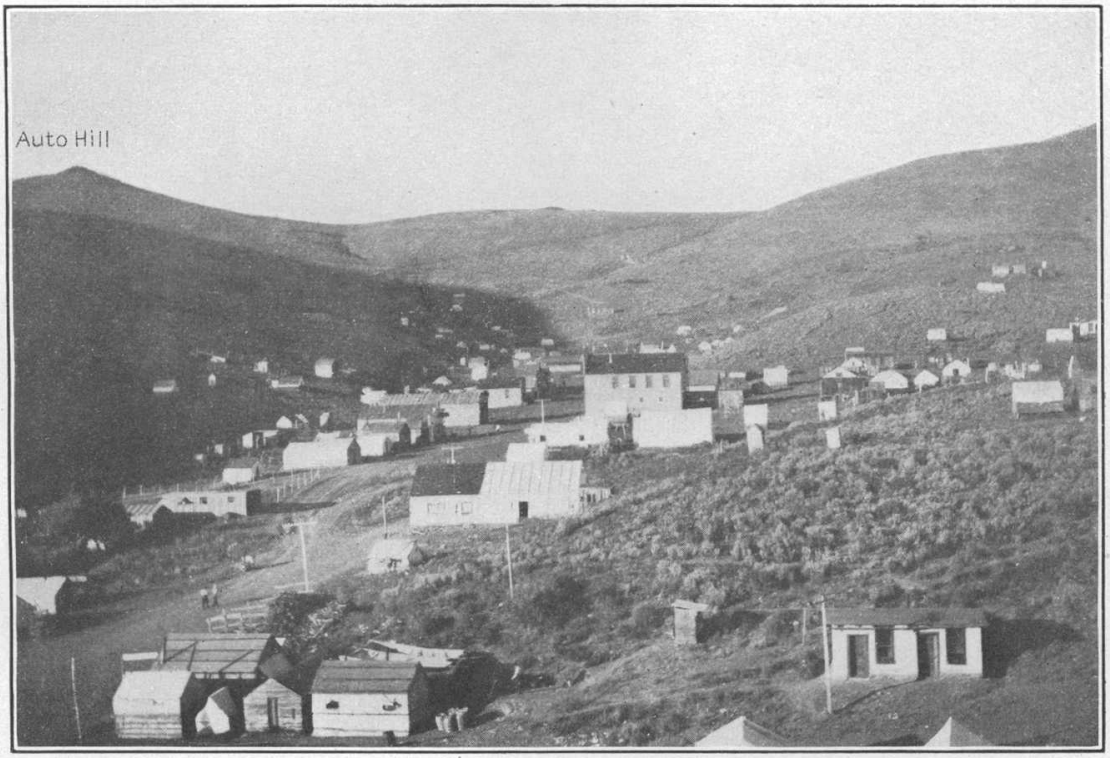

A. GENERAL VIEW OF NATIONAL, NEV., LOOKING EAST.

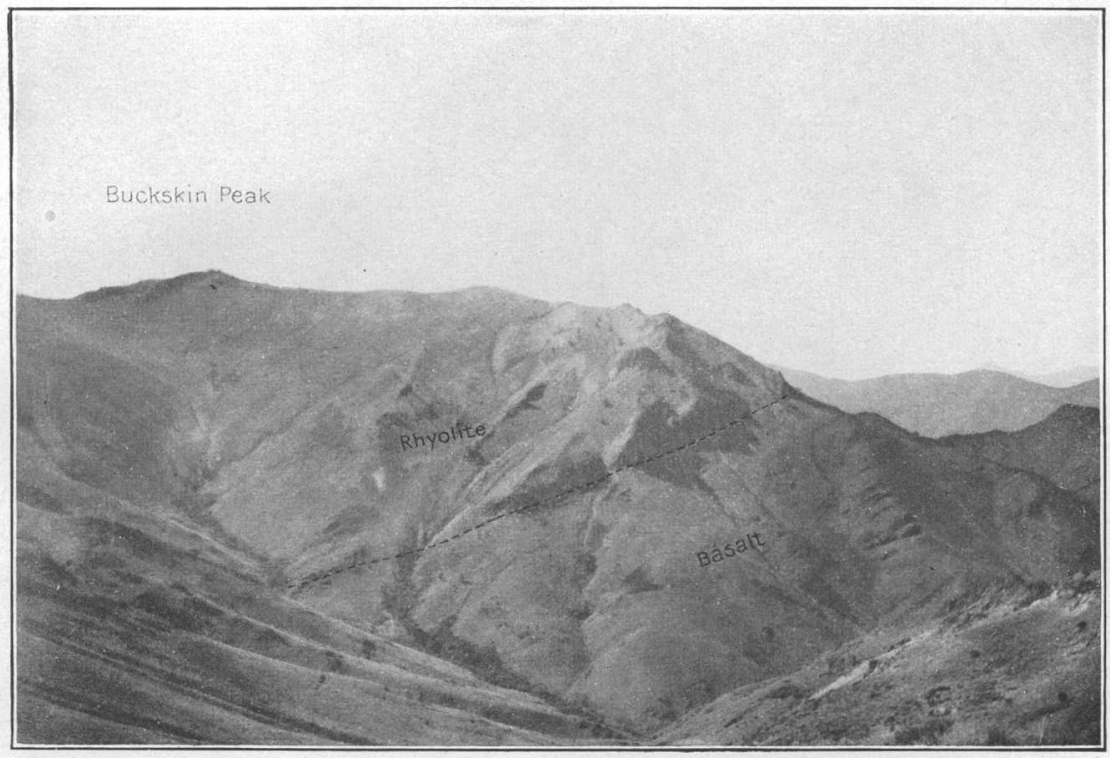

B. BUCKSKIN PEAK, LOOKING SOUTHEAST. 
To the south, behind the hills that overlook the town, a deep gash indicates the upper canyon of Threemile Creek. At its headwaters rises Buckskin Peak, reaching an elevation of 8,800 feet-a huge yellowish-gray pile of rhyolite resting on basalt flows and harboring under its craggy cliffs glistening fields of snow. To the north Eightmile Creek trenches the dark volcanic rock, a bright green ribbon of small cottonwood trees marking the course of the stream. The slopes on the north side of this canyon would hardly delight a forester, but can not fail to interest the geologist, with their wonderfully marked lava flows, dull brown and somber, inclining evenly toward the east.

Charleston Gulch, also heading near Buckskin Peak, is a deep gash cut in the lavas a mile east of the little town, and the National mine, easily preeminent among the attractions of the camp, lies on one of its smooth slopes, with a background of rough basalt. The mine is separated from the town by a low divide and is not directly visible from points near the settlement.

The whole landscape is a wonderful exhibition of the effect of erosion on a region of volcanic flows. Not always, however, is it as pleasing as described above, for the winters begin early and last long, and fierce blizzards cover the bare slopes with a mantle of snow.

\section{HISTORY.}

PROSPECTING AND MINJNG.

During the prospecting in Nevada that followed the discovery of the Comstock mines the Santa Rosa Range was not overlooked. Prospecting began here about 1868, or even earlier. A number of deposits were found along the range from Winnemucca Mountain to Buckskin Peak. The prospecting was confined almost entirely to the pre-Tertiary deposits; the bonanza of National camp was not uncovered until 1908, although the veins on the summit line just north of Buckskin Peak have been known for many years.

About 1884 the Spring Mountain district was worked with considerable success, and prospecting was carried on at many places in the southern part of the range, but interest waned with the drop in the value of silver, and from 1891 to the present time no mining has been done on the old properties.

The deposits at National were discovered in 1907 by J. L. Workman, who entered the district by automobile and named the striking points in the vicinity after parts of his machine. $\mathrm{He}$ found encouraging indications and made many locations, some of which covered the ground of the present National mine. In August, 1908, ore containing both silver and gold was found on Charleston Hill, and 5 tons were shipped to the Selby smelter, near San Francisco. The smelter 
returns were only $\$ 40$ a ton. 'The property' held by Workman was divided into many small lease blocks, which were taken by Stall Bros., Kendall, Gayer, Donalson, and others. . Stall Bros. bought out some of their neighbors, and in 1909 rich ore was discovered at the Stall shaft about 40 feet below the surface. Much rich ore, averaging $\$ 30$ a pound, was shipped. Meanwhile other parts of the district had been prospected, but generally with indifferent success.

In July, 1910, the two Stall brothers were seriously injured by the caving of the hanging wall. The mining of the incredibly rich ore continued without their personal supervision, but, as may well be imagined, the results were not satisfactory, and in 1910 the Stall Bros. sold out to the National Mines Co. of Chicago, of which J. G. Snydaker is president and L. G. Campbell, of Winnemucca, vice president.

Up to November, 1910, the production is believed to have been approximately $\$ 1,700,000$. In 1911 the exploitation of the narrow rich shoot was in progress, and the total production was said to have reached $\$ 4,000,000$.

During the same year adjacent ground was prospected by the National Mines Syndicate, controlled by J. L. Workman, and by the Mammoth National Mining Co., Gordon Campbell in charge, which owned ground adjacent to the National Mines Co. In 1911 a law suit was begun by the National Mines Co. against the Charleston Hill National Mining Syndicate and the Mammoth Mines Co., alleging trespass. This suit culminated in a notable trial at Carson, Ner., in which mining experts and geologists such as $\mathrm{H}$. V. Winchell, A. N. Winchell, and A. C. Lawson, figured prominently. Further notes regarding this trial will be found on pages $52-54$.

The camp has had a checkered history. When the rich ore shoot was discovered adventurers and gamblers of all kinds flocked to National, with the usual consequences. The high-grade ore invited pilfering as well as stealing on a large scale. On two occasions armed men broke into the mine and stole a number of sacks of rich ore. A searchlight was then erected, whose rays played during the night on the entrance to the mine. In 1912 another bold attempt was made to steal some rich ore belonging to the Mammoth National Co. In short, the brief but exciting history of the camp-largely a history of the National mine-illustrates well the dangers and annoyances connected with the mining of exceptionally rich ore, not only from robbers, but also from processes of law, the apex law of the United States being a constant and irresistible temptation to clever interpreters of the statutes.

IEASING.

Nearly all the properties in the camp were locáted by J. L. Workman in 1907, a fact that in itself shows a weakness of our mining law. Workman subdivided his claims into small leases, about 100 
by 300 feet or 250 by 200 feet, and thus work was begun at many points in the district, but no notable results were obtained except at the Stall Bros. lease.

The terms of the leases, most of which ran for 1 year or 15 months, provided for payments to the owners on ore assaying $\$ 50$ or less per ton, 10 per cent; on ore assaying $\$ 50$ to $\$ 150$ per ton, 15 per cent; on ore assaying $\$ 150$ to $\$ 250$ per ton, 20 per cent; on ore assaying $\$ 250$ to $\$ 1,000$ per ton, 25 per cent; on ore assaying over $\$ 1,000$ per ton, 40 per cent.

A few thousand tons of low-grade ore, assaying about $\$ 100$ a ton, were thrown on the dump of the National mine, but the ore shipped averaged about $\$ 30,000$ a ton in gold of a value of $\$ 10.60$ an ounce.

According to a statement in one of the Stall leases the first-class ore during a certain period was worth $\$ 24.84$ a pound, and the second-class ore $\$ 4,000$ a ton. A sample statement from the Salt Lake United States assay office gave, for instance (after melting), 644.45 ounces of bullion, containing $\$ 6,687$ in gold and $\$ 166$ in silver. At first the gold quartz was reduced in a small amalgamating pan, but later the National Mines Co. put up a 5-stamp mill with concentrating tables.

\section{GENERAL GEOLOGY.}

The northern part of the Santa Rosa Range, from Canyon Creek northward, is built up of Tertiary lavas, among which basalts in many superimposed flows predominate. Only a small area near the camp was carefully studied (see Pls. I and II and fig. 3), and as neither the eastern nor the western foot of the range was examined in detail, the whole story of the volcanic period can not be told here. So far as known it is simple.

In the present topography there is no trace of the cones or craters of a volcanic region. The deformation of the flows, expressed by an east or northeast dip of $8^{\circ}$ to $15^{\circ}$, and the deep erosion show that the rocks are rather old. Though no fossils were found we shall probably not be greatly mistaken in assigning a Miocene age to these flows. Their resemblance to the Columbia River basalt is in many ways clearly apparent to one who has studied these volcanic flows in Oregon, Idaho, and Washington.

The basal part of the series was studied only along Canyon Creek, where basalts immediately overlie clay slates. Along Eightmile Creek the basalt probably reaches the foothills, but on Threemile Creek some rhyolite flows appear to be intercalated in the lower series. North of Eightmile Creek only basalt flows were seen, but at National the flows are of several kinds. The basal rocks at National are basaltic tufts and some distinctly water-laid lacustrine strata. 
Above these rests on Round Hill a distinct flow of latite, which appears also on Radiator Hill with trachytic facies. These rocks were covered by many successive basalt flows, now eroded about the town

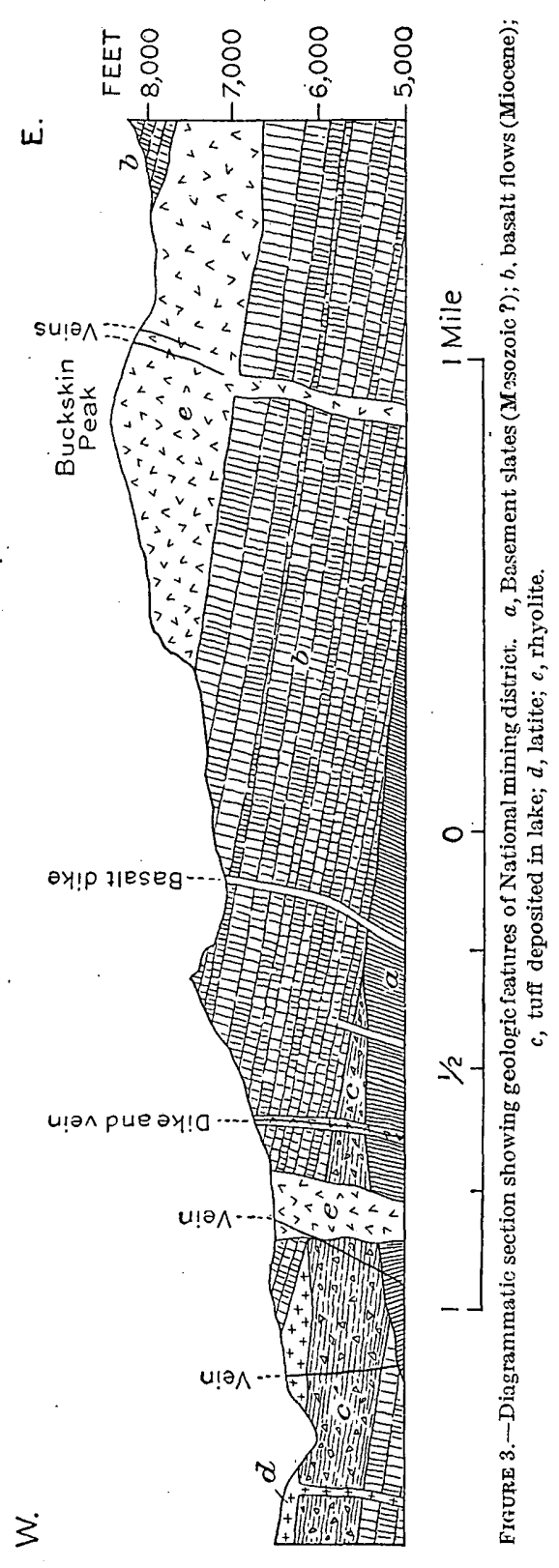

but still visible on the surrounding ridges.

The tuffs were intersected by dikes and necks of the later basalt, and finally, toward the end of the volcanic cycle, there followed a thick effusion of rhyolite, which now forms the top of Buckskin Peak. Probably about the same time numerous necks and dikes of rhyolite, most of them trending due north, penetrated all the older flows. After this rhyolite eruption, during the last stages of volcanism, basalt again poured out in flows that are mainly exposed near the summit of the range.

The latite at the National mine is almost identical with that at Round Hill and is probably part of a flow. At any rate it is older than the rhyolite at the mine.

The upper rhyolite is the one important rock in the mineralization.

No definite conclusions were reached regarding the structural development of the range, but the regular northeast dip of $8^{\circ}$ to $15^{\circ}$, which can not be original or initial, indicates that the whole succession of flows, probably including those on the western side of Quinn River valley, was domed; it is likely, therefore, that this valley near $\mathrm{Na}$ tional represents an area depressed between fault lines. The valley border as far as examined shows, however, no topographic eridence of faulting. 


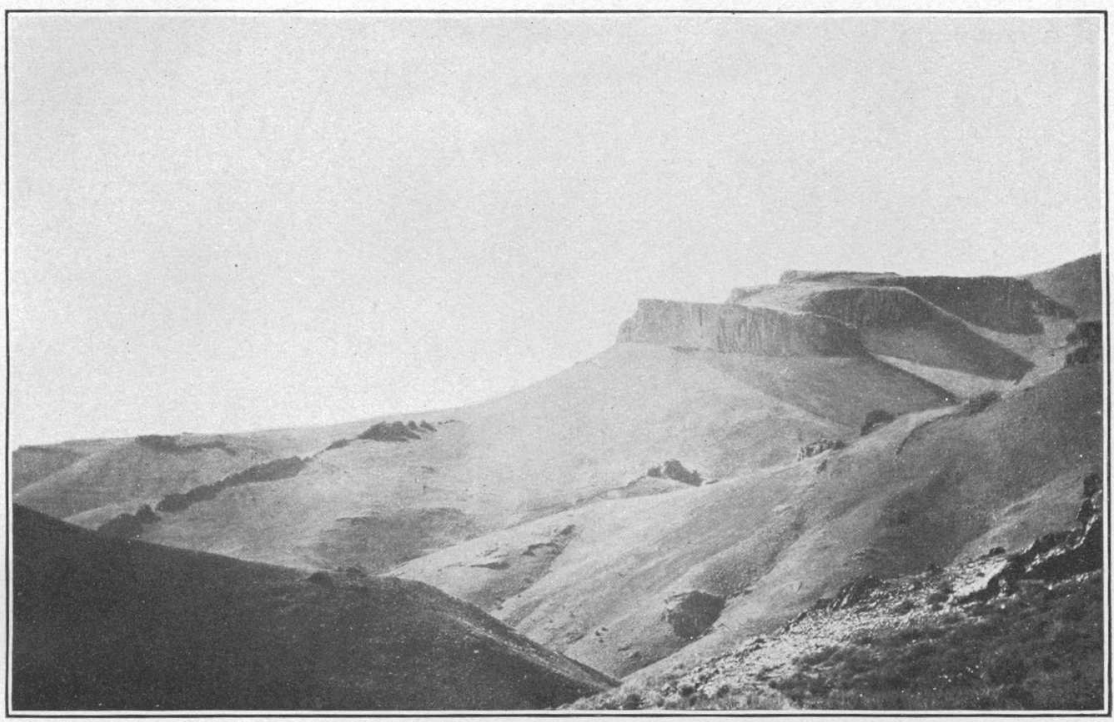

A. WEST SLOPE OF RANGE NORTH OF EIGHTMILE CREEK.

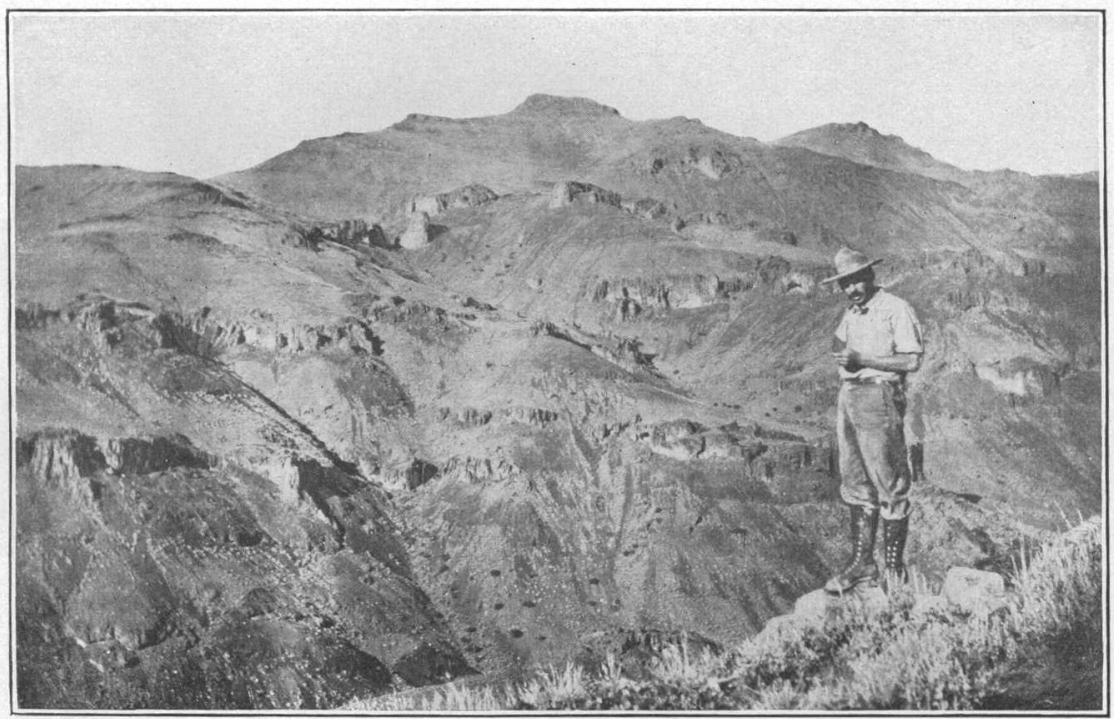

B. BASALT FLOWS NORTH OF EIGHTMILE CREEK. 


\section{THE ROCKS.}

\section{BASALT.}

Distribution.-The predominant rock in the district is basalt, and it occurs most commonly as flows superimposed one upon another in thick series. These flows are tilted gently northeastward at an angle of about $15^{\circ}$ at most and are strikingly exposed in the trenches of Eightmile and Threemile creeks. (See Pl. III.) The total thickness of these rocks shown at any one place is probably not over 2,000 feet, but one gains the impression, which is verified by sections, that the whole sequence, including the rhyolite, from National camp to Buckskin Peak, must represent a thickness of 5,000 feet. As one flow covered another it is not surprising to find necks and dikes of basalt in the lower series. Such dikes are exposed near the schoolhouse at National, where they cut lacustrine beds of tuff. Auto Hill is probably a neck of basalt cutting up through the same soft tuffaceous masses.

The flows of basalt are generally thin, few being over 50 feet thick. The general color of the basalt is dark brown to reddish brown, and many flows are extremely vesicular and scoriaceous. No zeolites were observed. The base of the series on the south side of the district rests on clay slates of unknown age, which are well exposed along Canyon Creek, but along Eightmile Creek the base of the flows was not observed.

These thick flows of basalt have all the characteristics of the Miocene Columbia River basalt and probably represent the southern margin of this widespread formation.

Some time early in the period of basaltic eruption in the district there was at National a basin or lake into which tuffs and ashes were washed from the surrounding volcanic fields. Much of the upper basin at National and probably also much of the slope south of Eightmile Creek are underlain by such material. The gentle slopes, which bear a luxuriant growth of sagebrush, give evidence of soft underlying rocks, which are clearly exposed only in cuts and tunnels. In a small tunnel near the schoolhouse tuffaceous beds, dipping $20^{\circ}$ E., are exposed, and a tunnel 500 feet north of the schoolhouse, in the same gulch, exposes regularly and thinly bedded tuffs, dipping $15^{\circ} \mathrm{NNE}$.

Unstratified tuffs are found at several places; for instance, in the small tunnels on the Friction claim, north of the hotel; at the Chefoo tunnel; and at the Morning Star tunnel, a few hundred feet below the National mill.

Petrography.--There is no essential difference between the basalts of the several flows, although parts of the same flow may differ rather 
conspicuously in texture. Some parts are almost diabasic and holocrystalline, containing little olivine. Others are more normal, finetextured basalts with a little interstitial dark-brown glass. Olivine is found in many rocks, but is by no means universally present. Many flows contain phenocrysts of labradorite; but that the rocks on that account should be separated into an intermediate class, as proposed by A. N. Winchell, ${ }^{1}$ does not seem advisable-certainly not in this district. Winchell proposes to designate the olivine-free basalts as "auganites," their main difference from ordinary olivine basalts being that they contain somewhat more silica and less iron and magnesia. The average "auganite" should, according to Winchell, contain 55 per cent $\mathrm{SiO}_{2}$ against 49 per cent in the average basalt. I have found no "auganites" at National, and even should they exist the series between the basalts and the "auganites" would be so continuous that the proposed distinction would serve no useful purpose.

A basalt collected along the road 5,500 feet northwest of National tunnel No. 5 is a normal fine-grained olivine basalt containing a few large phenocrysts of labradorite. It shows typical intersertal texture with scanty glass and dendritic magnetite. According to R. C. Wells, of the United States Geological Survey, it contains 48.58 per cent $\mathrm{SiO}_{2}$.

A second basalt, from the neck forming the summit of Auto Hill, is a holocrystalline fine-grained basalt containing augite and labradorite but no olivine. According to Wells the rock contains 52.84. per cent $\mathrm{SiO}_{2}$.

A third basalt, from a dike in tuffs at the schoolhouse, is a normal fresh basalt with holocrystalline diabasic texture. It consists of augite, labradorite, and magnetite, with phenocrysts of labradorite, but no olivine. According to Wells the rock contains 48.26 per cent $\mathrm{SiO}_{2}$.

Much of the basalt exposed by mining is considerably altered. Some of these basalts contain true amygdules of calcite; but in most of the apparent amygdaloids the carbonate, which contains besides calcium much magnesium and iron and is associated with chlorite, forms very pretty pseudoamygdules, in which a radial concentric structure of the secondary replacement minerals gives the impression of filled cavities. All the carbonates are secondary. In places these basalts are rich in marcasite or pyrite and the feldspars may be sericitized.

\section{LATITE.}

Distribution.-Rocks of andesitic appearance outcrop in two separate areas, one at the National mine and the other on Round Hill, north of the town.

${ }^{1}$ Winchell, A. N., Geology of the National mining district, Nev.: Min. and Sei. Press, Nov. 23, 1912, p. 655. 
'The rock at Round Hill seems to be a flow resting on tuffs and lake beds. Near the gap between Auto and Round hills the lower contact is at an elevation of 6,500 feet, but toward the west it sinks to 6,300 feet, its altitude north of the hotel.

The rock weathers in brownish black, smooth, blocky outcrops, breaks easily, and rings under the hammer. It is at some localities regularly laminated in plates 1 inch to 3 inches thick. At many places it breaks in sherds or smooth flat pieces.

The freshly fractured rock is dense and greenish gray, and contains a few small phenocrysts of feldspar and, more rarely, of hornblende. Inclusions or amygdules of quartz appear to be characteristic but nowhere plentiful.

A rhyolite dike 50 feet thick intersects the flow on the west side of Round Hill. It does not strike parallel to the rhyolite dikes that occur farther east but trends $\mathrm{N} .50^{\circ} \mathrm{W}$.

The exposures at the National mine are harder to decipher. The appearance of the rock is sufficiently indicated above. The greenish-gray color on fresh fracture, the laminated structure, and the absence of phenocrysts, except a few small feldspar crystals or rare prisms of black or greenish hornblende, are characteristic.

The rock outcrops along the east slope of the National gulch around the tunnels of the National mine and forms the larger part of the country rock in the workings. The highest point at which it is found is on the slope 50 feet below the Stall shaft. It thus forms a rather narrow area surrounded by areas of basalt and rhyolite. Its relations to the surrounding rocks are not altogether clear, but it appears to be intersected by dikes of rhyolite.

General petrography.-Most of the material obtained in or near the mine is so greatly altered that its original character can not be determined with certainty. The Round Hill area contains fresher rock, especially near the summit, the lower part of the flow, which rests on tuff, being more or less altered.

In general, the rock, which is trachytic in texture, contains scant and small phenocrysts of oligoclase and andesine, more rarely small prisms of green hormblende. The groundmass consists predominantly of microlites of feldspar ranging from oligoclase to andesine, among which are many microlites of orthoclase. In one specimen of fresh rock small prisms of augite are fairly abundant, but, as a rule, the ferromagnesian silicates are represented only by chlorite. Magnetite in small octahedrons and apatite in slender prisms are rather abundant. Although a colorless siliceous glass was found in one thin section, most of the specimens contain no glass. Quartz is rather abundant and fills miarolitic cavities, into which prisms of feldspar and apatite project. Larger quartz blebs occur in many specimens from both areas and have the appearance of inclusions. 
Altogether the rock is of unusual type. It is clearly of intermediate character, and as the quartz certainly appears to belong to a late magmatic period the best designation for it appears to be latite or quartz-latite. Its high content of potassium and its low content of calcium prohibit its classification as an andesite.

Rocks from Round Hill.-A specimen from the west summit of Round Hill is dark gray, dense, and has an almost flinty fracture. A few very small phenocrysts of feldspar were noted, some of which are andesine. Many of them are deeply corroded. The groundmass consists of short feldspar microlites, most of which are orthoclase. The twinned microlites appear to be oligoclase. Scattered through the groundmass are short, stout prisms of colorless augite, most of them attached to grains of magnetite, and numerous prisms of apatite. Between the feldspar laths is some almost colorless interstitial glass and here and there a little quartz. Secondary calcite is present in irregular aggregates.

A partial «nalysis of this rock gave the following results:

Partial analysis of latite (specimen 2SN).

[By R. C. Wells.]

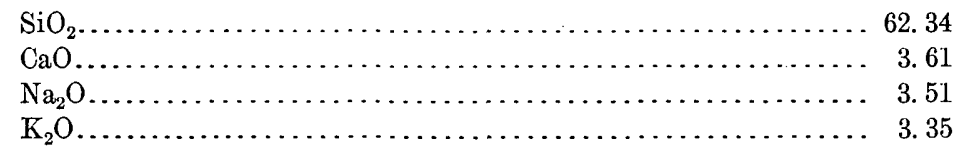

Other specimens from the east slope of Round Hill (as specimen $21 \mathrm{~N}$ ) are dark-gray fine-grained rocks, containing some blebs of quartz. Under the microscope these rocks are seen to be more chloritized than the one just described and more closely resemble the rocks from the National mine area. They contain a few phenocrysts of andesine, and the groundmass is an aggregate of feldspar microlites, many of them stout, others rather slender. A larger proportion of the microlites are striated than in the rock already described, and the angles of extinction and indices of refraction indicate that the rock contains both orthoclase and oligoclase. No glass is visible. The interstices between the feldspar laths are filled with quartz, into which the ends of the microlites project. This quartz is also penetrated by abundant slender prisms of apatite. Magnetite is fairly abundant in well-defined equidimensional crystals. There is much chlorite, but it is not evident from what ferromagnesian mineral it has been derived. Calcite in irregular aggregates has replaceả feldspar.

Rocks from National mine.-Typical latite was collected from the rock cut in excavating for the foundations of the mill. It is dense, greenish gray, somewhä i chloritic, and contains no phenocrysts and no visible quartz. 
Under the microscope the rock proves to be a mass of feldspar microlites, a few of them striated. Their index of refraction is generally lower than that of quartz. They give the impression of trachytic texture (as in specimen $23 \mathrm{~N}$ ), but there appears to be no glass. Quartz in microlitic cavities, into which apatite and feldspar crystals project, is fairly abundant. The rock contains scattered magnetite in well-defined regular crystals and abundant secondary minerals. Chlorite is generally distributed through it, and has replaced crystals of feldspar. Calcite in irregular aggregates, also replacing feldspar, and a few foils of sericite complete the list of products of alteration.

A partial analysis gave the following result:

Partial analysis of latite (specimen $48 \mathrm{~N}$ ).

[By R. C. Wells.]

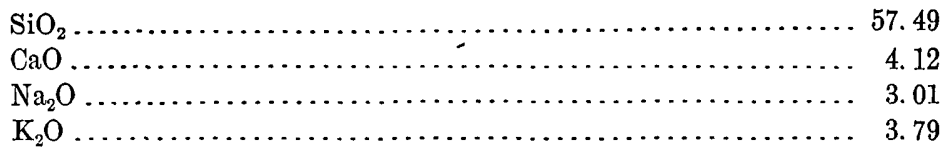

In spite of somewhat lower silica, in part due to extensive chloritization, the relationship of this rock to the rock from Round Hill (specimen $23 \mathrm{~N}$ ) is apparent.

Another specimen collected higher on the slope, near No. 1 post, West Virginia claim, shows a phenocryst or two of sanidine and one or two prisms of green hornblende." The rocks collected in the mine are similar to those already described. Specimens were obtained from level No. 5, 60 feet east of the vein (specimen 26) in crosscut; 140 feet north of Stall shaft (specimen 27); in crosscut east from Stall shaft 400 feet from the vein (specimen 30 ), and many other places.

All these rocks contain much calcite. The rocks near the vein also contain much pyrite and some sericite.

Relations and age.-These rocks seem to be related to the trachytic and rhyolitic rocks of National rather than to the basalts. As stated above, the area of Round Hill should be considered a flow of midbasaltic age. The latite of the National mine area may be intrusive, but I should rather consider it an eroded remnant of a flow still further cut up by the rhyolite intrusions.

TRACHYTE.

The Jower part of Radiator Hill consists of tuffaceous material and the south and west sides of basalt. The summit is occupied by a dark-brown rock, which looks much like a rhyolite and which covers a small area whose longest diameter extends from north to south. It was first thought to be a dike breaking through tuff and basalt. The exposures are not good enough to decide its character definitely, but it is now considered a part of the latite flow of Round Hill. 
The rock from the summit is dark brown and felsitic, and contains a few small crystals of sanidine. Under the microscope these phenocrysts of sanidine appear greatly corroded, and lie in a holocrystalline groundmass of small, short feldspar prisms, among which twin striation is rarely seen. A partial analysis gave the following results:

Partial analysis of rock from summit of Radiator Hill (specimen $24 N$ ).

[By R. C. Wells.]

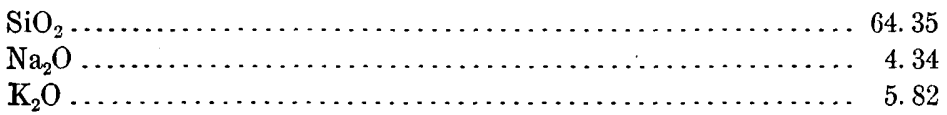

The above analysis indicates that the rock is a trachyte in which the combined alkalies exceed 10 per cent.

Specimens from the southernmost point of the same area are similar to the one just described and look like a dense felsitic rhyolite, one of the specimens being vesicular. Under the microscope the rocks are seen to be principally composed of orthoclase, but they also contain quartz in miarolitic interstices between the short feldspar laths. There is an unquestionable relationship between these rocks and the latite of the National mine.

A very similar rock occurs as a dike in Charleston Gulch 500 feet east of Casey's (Campbell's) tunnel, where it probably intersects basalt.

RHYOLITE.

Rhyolite is an impcrtant rock at National, for it is intimately connected with the mineralization. The main area consists of a flow which occupies the summit of Buckskin Peak and which toward the east is overlain by flows of basalt. The flow has a maximum thickness of at least 1,200 feet. Within the district proper rhyolite appears in a number of northward-trending dikes, most of which are to some degree mineralized. One of these extends from the town up to the west base of Auto Hill. On the north side of Auto Hill at least two dikes are traceable for more than half a mile. Another intrusive dike or mass lies near White Hill, from which it extends many offshoots in the general direction of National Gulch to the point of the junction of Charleston Gulch and Eightmile Creek.

These dikes undoubtedly came from the same source and were erupted at about the same time as the great rhyolite flow of Buckskin Peak. All of them break up through the older basalt flows and their associated tuffaceous beds. In thickness the dikes range from 25 feet to several hundred feet.

The petrographic features of these rocks are relatively simple. Most of them are whitish, have earthy or lithoidal fracture, and are 
typical rhyolites. Most of them carry phenocrysts of quartz and sanidine and some contain black mica in small foils. In a few dikes glassy obsidian is associated with the lithoidal variety of rhyolite.

The dike in the gap west of Auto Hill is about 50 feet wide. A specimen from the Blum shaft dump, said to come from the lowest level, now under water, is an earthy white rock containing scattered small crystals of pyrite and a few small phenocrysts of quartz. The microscope shows greatly corroded phenocrysts of quartz and sanidine in a microcrystalline, rather coarse groundmass formed of grains of orthoclase and quartz. The sanidine contains much kaolin and the groundmass contains fibers of sericite. Most of the dikes north of Auto Hill are similar to this one and many of them contain little veins carrying comb quartz. These dikes are said to contain a little silver and gold and mining claims have been located on their outcrops, which are usually stained by limonite.

The rhyolite of the second belt of dikes is 300 feet wide at a point south of White Hill, on the ridge overlooking Threemile Creek, and much of it is brecciated and glassy, especially on the west side. In some parts of the dike irregular masses of obsidian are contained in the normal rhyolite. On White Hill the dike swells to a width of about 800 feet and the rock is light gray, lithoidal, and contains small yellowish phenocrysts of feldspar and small scattered foils of an unusually black biotite. The groundmass is cryptocrystalline and in places felsitic. The rocks farther north are in part similar to that just described, but much of the material in National Gulch is earthy, white, and has been more or less affected by mineralization. In the gap at the head of Charleston Gulch, almost due north of Buckskin Peak, a mass of rhyolite containing much obsidian is found on the west side. This also is probably an intrusive mass in spite of its abundant content of the glassy variety of rhyolite. On the east side of the gap, capping a hill several hundred feet above it, is another small area of rhyolite. The rhyolite of Buckskin Peak is lithoidal, dense, light yellowish or brownish gray, breaks into small fragments, and as far as observed contains no obsidian. It appears to be a normal rock of its kind. At the top there is much silicification, which results in jagged, irregular outcrops. Small phenocrysts of quartz are plainly visible in the dense silicified mass.

The association of irregular masses of obsidian with lithoidal rhyolite in many of the dikes is interesting and somewhat unusual. 


\section{MINERAL DEPOSITS.}

\section{GENERAL CHARAOTER.}

The mineral deposits at National (see Pl. IV) are narrow fissure veins with a northerly trend and steep east or west dip.

The strike and dip of some of the veins at National are shown below:

\begin{tabular}{|c|c|c|}
\hline Location. & Strike. & Dip. \\
\hline 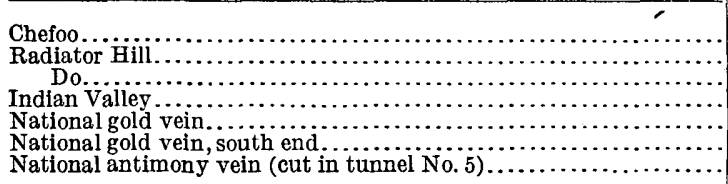 & 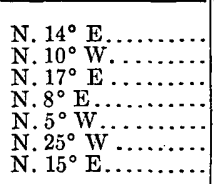 & $\begin{array}{l}80^{\circ} \mathrm{W} \\
\text { Vertical. } \\
\text { Steep east. } \\
80^{\circ} \mathrm{W} \text {. } \\
60^{\circ} \mathrm{W} \\
55^{\circ} \mathrm{W} \text { SW. } \\
56^{\circ} \mathrm{W}\end{array}$ \\
\hline
\end{tabular}

The veins intersect latite, rhyolite, basalt, basalt tuff, and trachyte. They are therefore distinctly later than any rock in the district.

Except the National vein (see Pl. V) none of the deposits has been extensively developed.

The country rock near the veins is altered by the development of pyrite, calcite, and a little sericite and adularia, but this alteration does not extend over wide areas.

The veins consist of sheared rock a few feet wide and have a wellmarked footwall. Seams of quartz lie along foot, hanging, or intermediate walls.

The quartz seams generally show symmetrical banding by deposition and are often vuggy, small quartz crystals projecting into the cavities. The massive quartz is mostly fine grained. In some veins the marginal deposits are sulphides, for instance, fibrous stibnite (Pl. VI, $B$ ); in others, such as the National, the first deposit on each wall is translucent quartz in radial aggregates. Calcite and other gangue minerals are rare. Granular adularia was noted in the quartz of the Neversweat shaft.

The most characteristic mineral is stibnite, for it occurs in almost every vein that has escaped oxidation. Pyrite, chalcopyrite, arsenopyrite, zinc blende, and galena occur only in small grains, which of ten are among the first deposits. Cinnabar was found in the vein on Auto Hill.

The veins that carry much stibnite are usually poor in gold and silver. Specimens from the vein on Radiator Hill (see Pl. VI, B), which shows abundant fibrous stibnite, contain only a trace of gold and 12 ounces of silver to the ton. The beautifully crystallized stibnite of the Indian Valley vein contains practically no precious metals. A specimen with much stibnite yielded on assay a trace of gold and less than an ounce of silver to the ton. A picked specimen, 


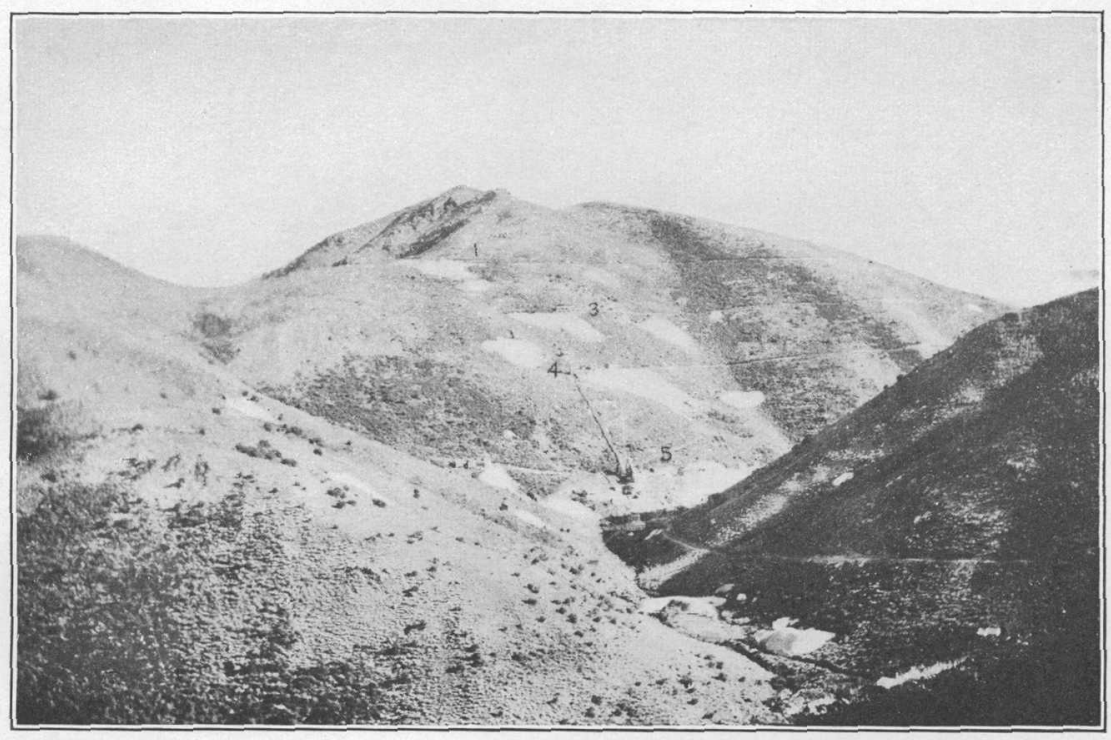

A. CHARLESTON HILL AND NATIONAL MINE, LOOKING SOUTHEAST.

1, Stall shaft; 3, tunnel No, 3; 4, tunnel No, 4; 5, mill and tunnel No. 5.

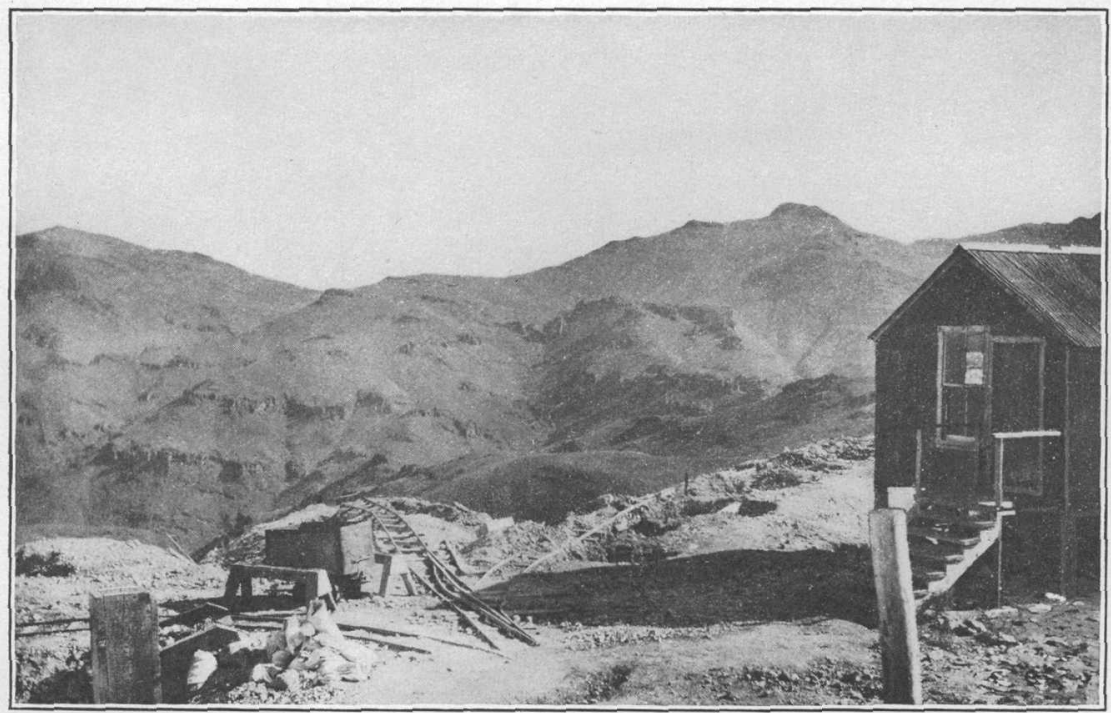

B. VIEW LOOKING NORTH FROM STALL SHAFT ACROSS EIGHTMILE CREEK. 
with sulphides, from the Chefoo vein, containing but little stibnite, gave 20 cents in gold and 16 ounces of silver to the ton.

The narrow veins on Buckskin Peak are likewise silver veins, but the ore in some of them is rich. Two specimens of vein quartz from the Neversweat shaft which contained a little pyrite gave on assay, respectively, $\$ 0.40$ and $\$ 1.40$ in gold and 21 and 105 ounces of silver to the ton.

Native gold is found chiefly in the rich shoot of the National vein, where it occurs as electrum containing about 50 per cent of silver.

The intimate connection of many veins with rhyolite dikes soon becomes apparent to the investigator. Claims have been located along most of the narrow dikes, and in the area south of the National mine much of the rhyolite is somewhat mineralized. The narrow dikes north of the National mine and Auto Hill contain veinlets of comb quartz, and it is reliably stated that this gives assays of 50 cents to several dollars a ton in gold and silver. A sample of such material from a sinall prospect 600 feet northwest of Blum shaft on Auto Hill was assayed by Prof. E. E. Bugbee and found to contain in fact a trace of gold and 7 ounces of silver to the ton.

The veins of National are therefore essentially silver veins of very moderate tenor, and the gold shoot of the National vein is a unique occurrence in the carnp.

The small quantity of silver ore of shipping grade that has been obtained was found near the surface and had doubtless been enriched by oxidation. Some of it was found also on Auto Hill in the mineralized rhyolite dike of that place. It contained ruby silver and silver chloride. Similar ore was discovered near the surface 30 feet south of the Stall shaft, practically at the outcrops of the National vein. It is said that it contained metal to the value of $\$ 134$ per ton, chiefly silver. According to the same informant, Mr. Roy Gayer, who was one of the earliest lessees, a body of soft "talc" was struck 30 feet west of the shaft at a depth of 17 feet. This ore contained $\$ 117$ per ton in silver and $\$ 0.80$ in gold. Ruby silver was probably the principal ore mineral.

The underground-water level stands near the surface. At the Stall shaft, which is on top of a ridge, water was reached at a depth of 40 feet. In the Blum shaft, on Auto Hill, which is also on the summit of a ridge but at a lower elevation than the Stall shaft, the water in June, 1911, stood 160 feet below the surface.

In the National mine, the only one with extensive developments, there is good evidence of the deposition of secondary sulphides below water level. Most abundant among them is marcasite, but there are also pyrargyrite and stibnite. No secondary gangue minerals were noted. The deposition of the sulphides takes place along joints and fissures, and the crystallization of marcasite is accompanied by considerable solution of quartz and the development of irregular cavities.

79102 - Bull. $601-15-3$ 
GOLD SHOOT OF THE NATIONAL MINE.

The one really important development in the camp is the gold shoot of the National mine. Encountered 40 feet below the surface in the Stall shaft, it has been followed on the dip of the vein a distance of about 800 feet, the stope length reaching 250 feet. Within this distance the vein carries much coarse electrum, or silver-gold alloy, mostly in the footwall seam, and much of the ore is extremely rich, averaging $\$ 20$ or $\$ 30$ to the pound. This high-grade ore is so irregularly distributed that entirely barren quartz may adjoin streaks of rich quartz a foot or two in width. Small grains of the common sulphides are found at the walls of the gold-bearing footwall veinlet, which is from a few inches to a foot wide and is beautifully banded by the alternating deposition of radial and fine-grained quartz. (See fig.6.) In places the quartz contains a little stibnite, but it is not directly associated with the gold. This gold shoot has been stoped down to the tunnel level No. 5, and it did not outcrop at the surface. The total production of this shoot is said to have been about $\$ 3,500,000$. It is not probable that any other shoots with coarse gold occurred in the mass of rock removed by erosion, for no placer gold has ever been found either in Charleston Gulch or along any other creek in the district.

\section{GENESIS OF THE VEINS.}

It has been stated above (p. 21) that the volcanic flows at National are probably of Miocene age. If this statement be accepted the vein system is necessarily of Miocene or post-Miocene age.

The close relations of the veins and the rhyolite, the latest rock in the district proper, is suggested by the fact that the veins follow the dikes and by the almost constant mineralization of the dikes.

Veins similar to those of National intersect the rhyolite flow of Buckskin Peak, and the summit of this mountain shows hot-spring action of the most pronounced kind, with development of chalcedony and silicified rhyolite, in which were found reddish-brown spots giving strong reaction for selenium.

There existed, then, an epoch of hot-spring action after the eruption of the thick rhyolite sheet, and it is probable that the waters ascended near the rhyolitic vents on fissures following the trend of the rhyolite dikes.

The veins have the symmetrically banded and vuggy structure which is so often seen in deposits formed near the surface by ascending hot waters, and this applies both to the gold-bearing and to the silver-bearing veins.

The composition of the veins - the fine-grained quartz, scarcity of pyrite, constant presence of stibnite, and occasional occurrences of 


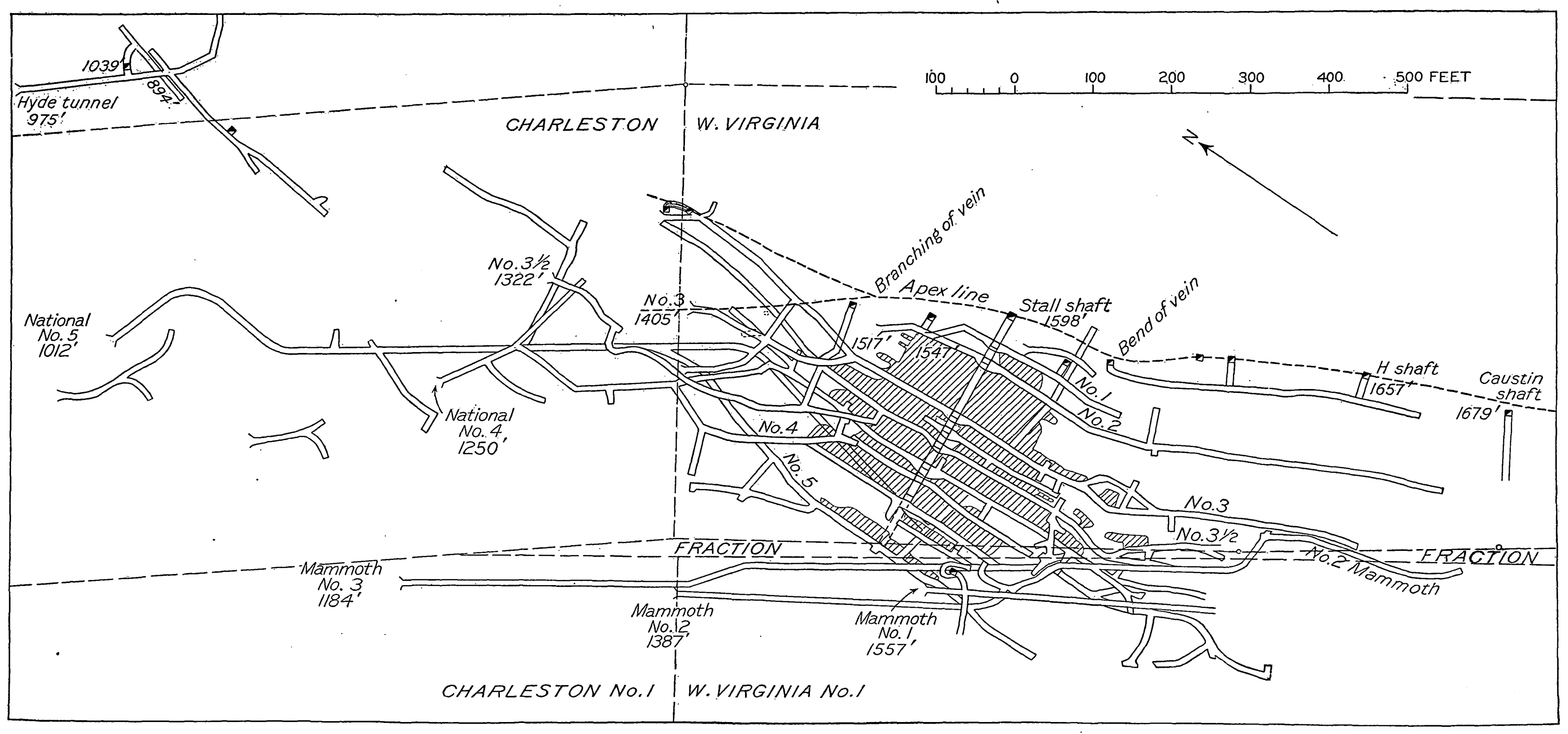

MAP OF NATIONAL MINE. 
cinnabar-points decidedly to deposition near the surface. The alteration of the country rock is of the propylitic type.

All this evidence strongly suggests deposition by ascending hot waters during a transitory thermal epoch which followed soon after the eruption of the Buckskin rhyolite.

On the assumption that the summit of Buckskin Peak marks the surface at the time of vein deposition it may be concluded that the veins on the mountain were formed about 1,000 feet below that surface and that the National vein at the lowest tunnel was formed 2,700 feet below the surface. As that surface necessarily was uneven these figures are of course only approximations.

The solutions contained much silica and some carbon dioxide or alkaline carbonate, besides some hydrogen sulphide or alkaline sulphides and a small content of metal. Probably their composition was somewhat like that of the Steamboat Springs of Nevada or the silica-sodium waters of the Yellowstone National Park.

The principal problem-that of the origin of the gold shoot of the National vein-must unfortunately remain without definite solution.

This much we can say, that in spite of many minor dissimilarities there is no fundamental difference between the origin of the goldbearing vein and the others. Surely it was formed during the same general epoch and by solutions originating from the same source. Parallel veins near the National vein are of the normal stibnite type and silver-bearing ores were deposited near the apex and to the south of the gold shoot in the same vein. Native gold occurs also in the National. vein outside of the pay shoot and occasionally in some of the other veins:

Nevertheless, the source of the gold, its remarkable localization, the strong contrast between the richest and the poorest quartz-in short, the cause of the ore shoot-are problems that have not been solved.

It is possible that there are, in depth, in the silver veins other gold shoots like that of the National vein, but the absence of placer gold in the gulches is a strong argument against such a supposition, for if the whole eroded mass contained no gold in its veins there is little likelihood of finding much coarse gold in depth.

\section{DETAILED DESCRIPTIONS.}

NATIONAL MINE.

Development and equipment.-.The National mine is contained mainly in the West Virginia and Charleston claims, on Charleston Hill. The vein was first found in the Stall shaft, on the ridge between Charleston and National gulches, and has been opened by several tunnels below that shaft, all entering on the slope toward 
the National Gulch, the lowest, No. 5, being at the gulch level. The locations of these tunnels are shown on Plates I; IV, $A$; and V.

Elevations were carried forward from Winnemucca to National by means of two aneroids. The elevation of National Hotel was determined as 6,050 feet. The relative elevations of the tunnels are taken from the mine maps. The elevations of the tunnels and levels are shown below.

\begin{tabular}{|c|c|c|}
\hline & Elevation. & $\begin{array}{l}\text { Distance be- } \\
\text { tween levels. }\end{array}$ \\
\hline Stall shaft, collar .. & ${ }_{6,708}$ & Feet. \\
\hline Tunnel No. 2 .... & 6,637 & 71 \\
\hline Tunnel No. 3 ...... & 6,521 & 116 \\
\hline Tunnel No. $3 \frac{1}{2} \ldots .$. & 6,442 & 89 \\
\hline Tunnel No. 4 ....... & 6,357 & 80 \\
\hline Tunnel No. $5 \ldots .$. & 6,130 & 22 \\
\hline Level No. 6. . ...... & 6,003 & 126 \\
\hline Level No. $7 \ldots$ & 5,876 & \\
\hline
\end{tabular}

The difference in elevation between the collar of the Stall shaft and tunnel No. 5 is thus 578 feet.

Except tunnel No. 3, which is driven on the vein practically from its outcrop, each tunnel enters the hill as a crosscut and soon encounters the vein, upon which drifting had been done in 1911 each way for 200 or 300 feet. In 1911 the developments probably did not amount to much more than 1 mile of workings. Tunnel No. 5 has the longest crosscut and encounters the vein about 600 feet from the portal.

Since 1911 much new work has been done, in part in connection with the trial described on pages 52-54, and levels Nos. 6 and 7 have been driven from a new winze 380 feet north of the Stall shaft on tunnel level No. 5 .

A small five-stamp mill with concentrating table is located at tunnel No. 5, but is operated only at intervals as ore accumulates. No ore of low grade-that is, below $\$ 25$ a ton-was treated.

About 1912 a small mill was erected at the Stall shaft for the purpose of treating the dump, which contained about 3,000 tons of material estimated to carry about $\$ 100$ per ton.

The ore is easily treated by the amalgamation process, as coarse electrum, an alloy of silver and gold, is the principal ore mineral, aside from a small quantity of ruby silver. In the early days of $1910^{1}$ the ore, averaging $\$ 20$ a pound, was crushed to pass a 60 -mesh screen. The pulp was then ground with quicksilver in a 4-foot 
amalgamating pan with mullers, 150 pounds being a charge, which was amalgamated for six hours. The tailings were shipped to the smelter. About $\$ 650,000$ was turned out by this little mill in less than three months. Second-class ore was not treated at that time.

After the mill was erected the higher grade of ore, containing from $\$ 10$ to $\$ 80$ per pound, was shipped and the lower grade was treated in the amalgamation mill. No ore containing less than $\$ 25$ a ton was treated.

During the earlier years the quartz was sorted in the mine and the high-grade ore only was taken out. Later the procedure was adopted of taking out all of the quartz in the stope and cobbing and sorting it at the surface because it often happened that small patches of high-grade ore were entirely surrounded by barren quartz and overlooked.

Geology.-All the rocks exposed are of igneous origin and are either surface flows or masses that were intruded near the surface.

Latite is the principal rock and occupies the whole slope below the Stall shaft to tunnel No. 5. The same rock lies on the dumps of all the openings. The first outcrop is seen 50 feet vertically below the Stall shaft. The latite is usually laminated and contains blebs of quartz.

Rhyolite outcrops on the slope both north and south of the narrow area of latite and is also observed on the dump of the Stall shaft. At a point 120 feet south of the shaft, on the point of the ridge, the supposed croppings of the vein (here chiefly silver bearing) are seen in pyritic rhyolite.

Basalt outcrops on the ridge above the Stall shaft and also on the crest of the lower ridge separating Charleston and National gulches.

In the workings of the mine practically all the country rock seen is latite, though the rock near the vein is often so much altered as to make its identification difficult. No rhyolite was found in the lower workings of the National Mines Co.

Basalt was encountered at one place only, 200 feet north of the Stall shaft on level No. $3 \frac{1}{2}$, between the main vein and a stringer.

The tunnels in the properties adjoining on the south side are mainly in rhyolite and basalt, and in these the southerly continuation of the National vein has been looked for.

Mammoth tunnel No. 1, at an elevation of 6,672 feet, starts in rhyolite, but in 58 feet encounters black basaltic rock.

Mammoth tunnel No. 2, at an elevation of 6,499 feet, enters in rhyolite, but 100 feet from the portal encounters latite. This continues to a point close to the National vein, where it enters basalt.

Mammoth tunnel No. 3, at an elevation of 6,300 feet, was 500 feet long in 1911, all in rhyolite, although the rock then visible at the breast was pyritic and looked more like mineralized latite. 
Alteration of country rock.-Close to the vein the latite is somewhat bleached, greatly decomposed, and pyritic, but rarely becomes a typical sericitic rock. The alteration develops much calcite and pyrite and a little sericite, but the rock is often greenish and fairly fresh looking, even near the vein. In many places it is traversed by narrow drusy quartz veins, and in some of these adularia in its usual crystal form, ordinarily attached to the walls, was observed, but it is not abundant.

In the upper tunnels the decomposed rock is greatly softened by surface oxidation and near the vein is converted into a yellow tenacious clay.

The vein.-The National vein is best exposed in the lower levels, as the ground in the upper levels is soft and caving.

The voin is traceable on Charleston Hill for about 2,000 feet. On both sides of the Stall shaft the vein strike almost due north, but a

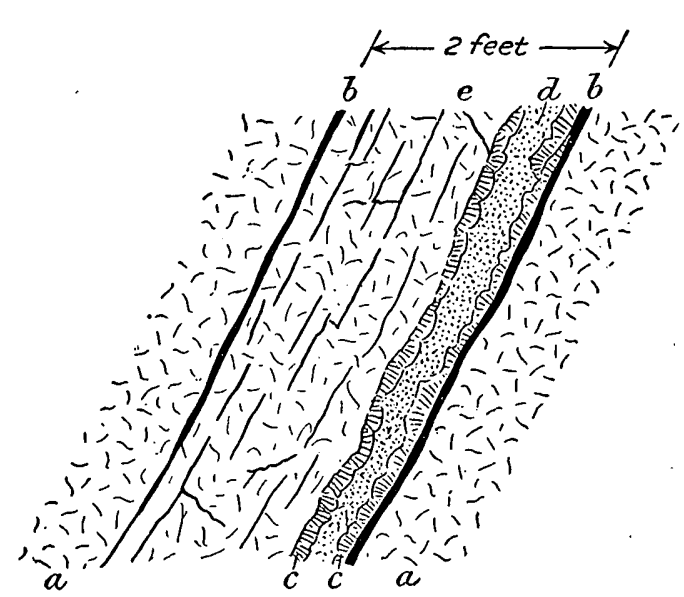

Flgure 4.-Diagram of National vein in tunnel No. 5 , near crosscut. Width of vein, 2 fect. $a$, Slightly altered latite; $b$, gouge seams on foot and hanging walls; $c$, radial translucent quartz; $d$, white, fine grained quartz; $e$, altered and pyritic latite, with slips and gouge seams. short distance south of this shaft it bends to a strike of N. $25^{\circ}$ W., and north of the shaft it breaks up in two branches, one trending a little to the west and the other a little to the east of north. The junction of the two branches as well as the bend is indicated on Plate V. The vein $\operatorname{dips} 50^{\circ}-60^{\circ}$ W., and has been followed along the dip for 675 feet to the lowest (No. 5) tunnel level, and in all 975 feet down to the winze level No. 7. (See figs. 7 and 8.)

The vein is 2 to 5 feet wide and usually has well-developed foot and hanging walls, generally with a gouge streak on the footwall. Most of the vein is soft, mineralized rock divided into several sheets by slips and false walls. (See fig. 4.) Narrow streaks of quartz, seldom more than 6 inches thick, lie on the footwall, more rarely on the hanging wall or in the middle part of the vein. At the bend of the vein, it is stated, the quartz was in places several feet thick.

It is evident that much comparatively late movement has taken place along the footwall, though within the West Virginia claim the movement has not been great enough to bring the latite in contact with rhyolite or basalt. In many places the quartz is entirely crushed, brecciated, or broken into fragments that have been more 
or less completely rounded. The quartz is plainly banded. Next to the footwall one finds ordinarily a layer of semitransparent, often radial quartz from 2 to 10 inches thick, with drusy surface.

Detailed notes. - No examination was made of the stopes above the third level as they were largely inaccessible and the rock extremely clayey and oxidized. There are no important crosscuts in this part of the mine.

Tunnel No. 3 intersects the vein 100 feet from the portal. The vein here strikes N. $5^{\circ} \mathrm{W}$. and dips $60^{\circ} \mathrm{W}$. It is only about 1 foot wide and is composed of several layers of quartz in soft rock, with intervening seams of clay. The vein here is softer and more clayey than on the lower levels and is stained yellow by antimony oxide. Two hundred feet south of the shaft on this level the vein bends sharply and strikes N. $35^{\circ} \mathrm{W}$. The ore shoot lies mainly north of this bend.

A descent through the rich but narrow stopes is interesting, though the soft claylike vein filling makes observations difficult. The vein is 5 to 6 feet wide and on the whole looks like a brecciated mass of rock with streaks of black gouge and small veins of quartz. In the rich stopes between levels Nos. 3 and $4 \frac{1}{2}$ the vein is similar throughout, consisting of a few feet of altered rock, soft and white, with good footwall, and is traversed by several gouge walls. The vein is at many places brecciated and marcasite is abundant on secondary slips and joints. Postmineral movements have here and there broken the narrow quartz veins and rounded the fragments. Rich ore is found in many such rounded fragments. There are some seams of quartz at the hanging wall and between the walls, but most of the high-grade ore is found in the vein of white quartz, which in so many places follows the footwall slip. (See figs. 4, 5, and 6.)

The rich quartz, though it forms a distinct shoot as a whole, is in detail very irregular. For some distance the footwall seam may be entirely barren and then suddenly rich and wholly irregular streaks begin and continue for a foot or two. The yellowish-gray electrum is extremely difficult to see by candlelight. Most of the rich quartz is translucent and the gold is seen in transmitted light and is also recognized by the rough feel of the rich pieces.

On level No. 5 the rock is fresher and permits a better examination. Tunnel No. 5 at first trends N. $70^{\circ}$ E., but soon bends sharply southward. The country rock is latite. The tunnel cuts two veins before it reaches the main vein at a point 600 feet from the portal. These two veins are well defined, with good footwalls. The first one strikes N. $15^{\circ} \mathrm{E}$. and dips $56^{\circ} \mathrm{W}$. It is 6 inches to 1 foot wide and consists of banded vuggy quartz and rather abundant stibnite. The second vein lies 75 feet farther east. Neither of the veins contains ore of value. 
The main vein on this level strikes true north and the dip is $56^{\circ} \mathrm{W}$. Its appearance is shown in figure 4 . The width between good walls of soft, altered rock is 2 feet, and there are several minor slips between the foot and the hanging wall. Marcasite appears on all slips. The

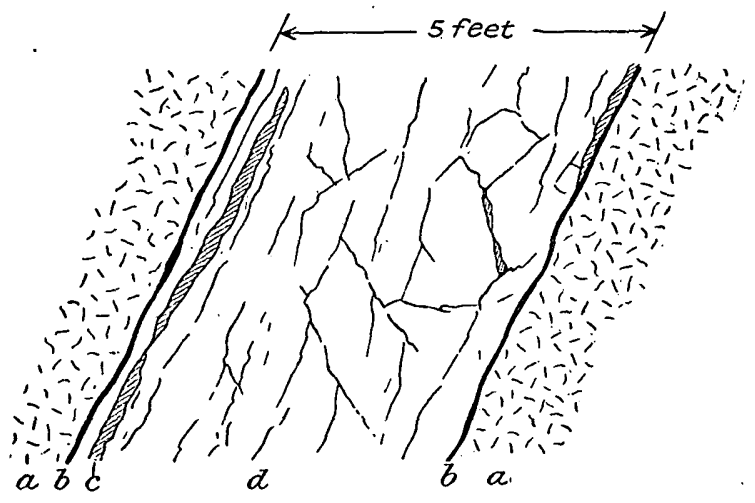

FIGURE 5.-Diagram of National vein in small stope just above tunnel No. 5. $a$, Slightly altered latite; $b$, gouge seams; $c$, quartz seams; $d$, altered, sheared, and brecciated latite, with fragments of quartz. footwall seam of white translucent quartz, 4 to 10 inches thick, shows radial drusy structure, clearly indicating filled spaces. In the quartz itself no sulphides are now visible, but yellow stains of antimony indicate the presence of stibnite. The vein is of no great value at this place, but con-

tains here and there a little gold and some silver. A raise was made from this level 150 feet south of the Stall shaft and some high-grade ore was found in it 120 feet above the level. (See fig. 5.)

A 400-foot crosscut in the footwall in tunnel level No. 5 disclosed no veins to the east.

Ore shoot.--The rich ore shoot was first found 40 feet below the surface near the Stall shaft.

The Stall brothers, who discovered this wonderful bonanza in 1908, were Californians from Marysville and had not had much experience in mining. Their shaft was located on a small block of ground, leased from Workman, at a point where some good silver ore had been found at the surface. The supposed croppings 40 feet south of the shaft are said to have yielded assays of $\$ 134$ to the ton, mostly in silver. About 30 feet west of the shaft, at a depth of 17

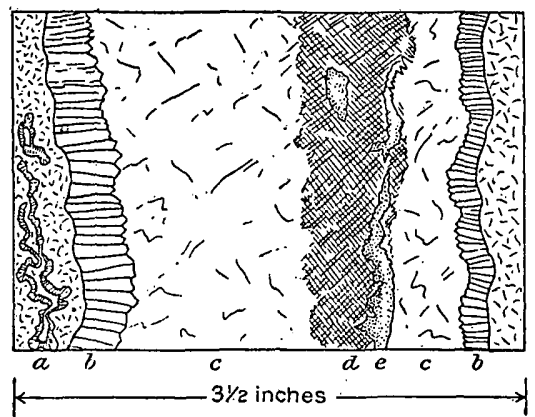

FIGURE 6.-Diagram of quartz seam in National vein in high-grade stopes between levels Nos. 4 and $4 \frac{1}{2}$. Width of seam, $3 \frac{1}{2}$ inches. $a$, Highly altered pyritic and siliceous latite with solution cavities covered with quartz crystals; $b$, translucent comb quartz; $c$, dull white, fine-grained quartz, usually carrying the gold; $d$, outline of entirely silicified rock fragment; $e$, later solution cavities coated with marcasite.

feet, a mass of kaolin was met which contained $\$ 117$ in silver and less than $\$ 1$ in gold to the ton. The gold ore was first found in the shaft 35 or 40 feet below the surface. It was extremely rich, especially in the footwall seam; much of the quartz was in rounded bowlders. The 
gouge carried nothing of value. The gold was pale and had a value of $\$ 11$ an ounce. There was a good deal of ruby silver both in the quartz and on seams and joints.

From the point where the ore shoot was first opened it widened rapidly. At first it was mainly worked close to the south side of the shaft, but later the stopes were materially extended and are now seen on both sides of the shaft. Little or no ore was found on tunnel level No. 5, but high-grade ore was encountered in raises from this level. On the dip of the vein it is about 675 feet from tunnel No. 5 to the collar of Stall shaft, and the ore shoot as far as stoped in 1911 occupied 550 feet of this distance, with an average stope length of

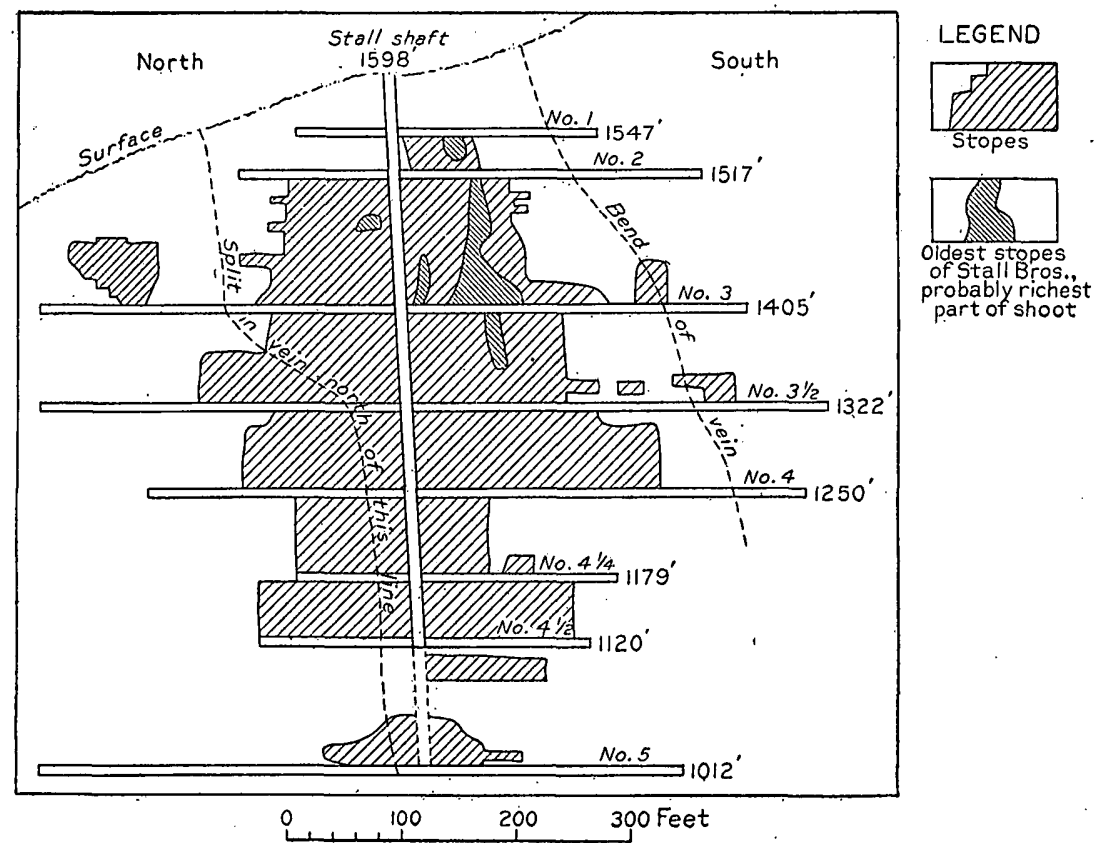

FigURE 7.-Longitudinal section of ore shoot, National vein.

perhaps 200 feet (figs. 7 and 8). There is practically no difference in the appearance of the vein within or outside of the ore shoot. In most places the rich quartz forms the footwall seam, averaging perhaps 6 inches of pure gold-bearing quartz (fig. 6). On the assumption that this footwall seam is equally distributed and 6 inçes wide the ore shoot had a content of 55,000 cubic feet, or a mass of $9,075,000$ pounds, a cubic foot of quartz being taken at 165 pounds. On the further assumption that the contents in precious metals were equally distributed, the total production of the shoot being taken as $\$ 4,000,000$, the ore would be worth about 44 cents per pound, or $\$ 880$ per ton. It is a fact, however, that the ore averaged about $\$ 20$ to 
the pound and consequently this high-grade ore must have been very irregularly distributed. Only one-sixtieth part of the quartz within the shoot was rich ore. This estimate agrees with the statements of the mine officers and with the writer's observation, for much practically valueless quartz was found within the ore shoot. Within the barren quartz the high-grade ore appears suddenly in streaks that are continuous only for a foot or two.

Specimen No. 38 (fig. 6), from within the ore shoot and close to high-grade quartz, was assayed by Prof. E. E. Bugbee and found to contain a trace of gold and less than 1 ounce of silver to the ton. The

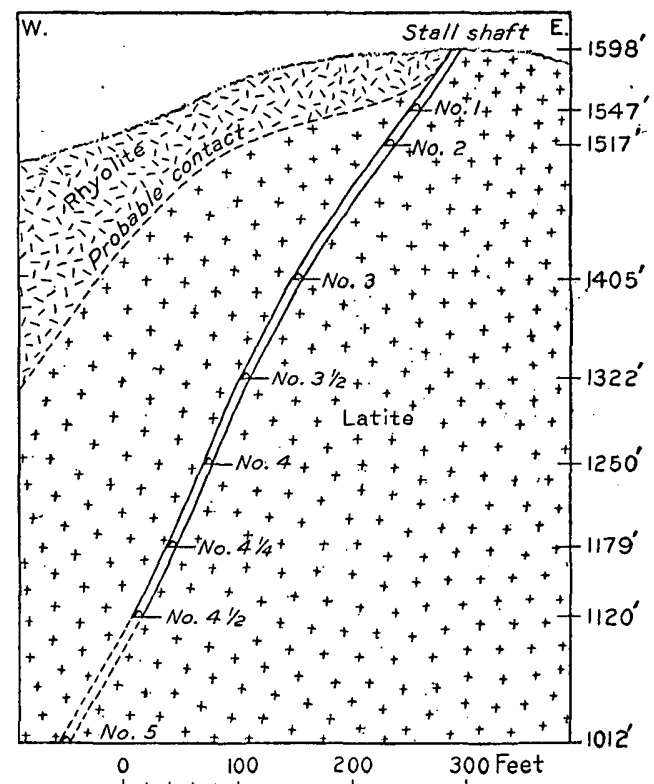

FIGURE 8.-Cross section of National vein along Stall shaft. sample was taken right across the specimen represented in figure 7.

Mr. S. Taylor, who was superintendent of the mine in 1911, stated, at the trial before the United States Circuit Court at Carson in 1912 , that on the No. $4 \frac{1}{4}$ level, just north of Stall shaft, he extracted $\$ 94,600$ in electrum from a very small block of ground, $\$ 70,000$ of which was taken from a slab of ore a few inches thick measuring 3 by 6 feet. At the same trial Mr. George Stall testified that 1 ton of ore shipped by him yielded $\$ 135,000$. The present superintendent, Mr. P. G. Harrison, testified that one shipment of 4,500 pounds made in 1911 (probably the same lot of ore which the writer saw at the mine) netted $\$ 81.20$ a pound, or a total of $\$ 365,000$. One of the foremen testified that he had taken out as much as 1,085 pounds of "high grade" in a shift of 8 hours.

Since the mine was visited in 1911 the stopes have been considerably extended. The stoped area now extends down to tunnel level No. 5 and some stoping has also been done between levels' Nos. 5 and 6. The stope length along the drifts ranges from 200 to 450 feet and the shoot, which dips steeply to the south on the plane of the vein, has a greatest axial length of 800 feet. Much of the quartz on the outside of the shoot was stoped in order not to overlook the sparsely scattered pockets of high-grade ore. Such rich pockets might occur within blocks which developments on four sides apparently showed to be barren. 
Though gold in paying amounts is confined within the shoot, specimens showing gold may occasionally be found outside of the shoot. Occurrences of this kind have been found in the Hyde tunnel and at several places in the National mine. In drift No. 2, south of the ore shoot, detailed assays of which are shown in the following paragraphs, visible gold was found at two places, although apparently no such occurrenees happened to be included in the assayed material.

Secondary silver minerals are irregularly distributed through the vein, and the isolated high assays in silver found in the table given below doubtless are caused by such occurrences. The author of this bulletin was informed by the present superintendent, Mr. Harrison, and the engineer of the company, Mr. H. L. Hollis, that ore has been developed recently on a new vein in the northern part of the property, in which also occurs electrum of the same character as that in the old vein, though with a little higher percentage of gold. This ore is also said to contain primary silver sulphides.

In order to show the values in the vein outside of the ore shoot the following assay list is introduced. The samples were taken at intervals of about 5 feet in the southern end of level No. 2 over a distance of about 330 feet. The assays are stated in ounces, thus: $\frac{0.02 \text { (oz. gold) }}{1.00 \text { (oz. silver) }}$. The uniform samples, each of a few pounds of quartz, were taken across the vein over a width of 1 foot to 6 feet. This statement of assays was taken from an assay plan introduced at the trial in Carson City (pp. 52-54) and numbered Complainant's Exhibit Q.

$$
\begin{aligned}
& \frac{0.08}{2.92}, \frac{0.06}{1.54}, \frac{0.04}{0.10}, \frac{0.04}{51.56}, \quad \frac{0.04}{0.12}, \quad \frac{0.02}{0.14}, \frac{0.02}{0.12}, \frac{0.02}{39.78}, \frac{0.06}{0.94}, \\
& \frac{0.06}{0.74}, \frac{0.04}{2.96}, \frac{0.04}{0.10}, \frac{0.04}{1.16}, \frac{0.04}{0.96}, \frac{0.02}{3.98}, \frac{0.04}{7.76}, \frac{0.02}{2.38}, \frac{0.04}{3.76}, \\
& \frac{0.06}{1.74}, \frac{0.08}{0.10}, \frac{0.02}{0.20}, \frac{0.02}{1.38}, \quad \text { illegible.] } \\
& \frac{0.02}{1.18}, \frac{0.06}{0.74}, \quad \frac{0.02}{0.38}, \frac{0.10}{1.50}, \frac{0.02}{1.18}, \frac{0.04}{0.10}, \frac{0.02}{0.58}, \frac{0.02}{0.78}, \frac{0.04}{0.10}, \\
& \frac{0.02}{0.20}, \frac{0.04}{7.56}, \frac{0.04}{0.15}, \frac{0.02}{0.12}, \quad \frac{0.02}{0.58}, \frac{0.02}{3.58}, \quad \frac{0.04}{1.96}, \frac{0.04}{2.38}, \frac{0.08}{3.32}, \\
& \frac{0.04}{0.06}, \frac{0.08}{1.32}, \frac{0.08}{6.92}, \frac{0.06}{11.14}, \frac{0.06}{12.24}, \frac{0.04}{23.56}, \frac{0.12}{14.48}, \frac{0.08}{4.32}, \frac{0.10}{9.70}, \\
& \frac{0.08}{1.12}, \frac{0.12}{3.88}, \frac{0.12}{4.88}, \frac{0.12}{4.48}, \frac{0.12}{9.08}, \quad \frac{0.40}{7.40}, \quad \frac{0.28}{0.72}, \frac{0.28}{31.12}, \frac{0.18}{8.00}, \\
& \frac{0.08}{6.52}, \frac{0.08}{2.52}, \frac{0.14}{4.92}, \quad \frac{0.10}{2.70}, \frac{0.14}{42.26}, \frac{0.08}{4.32}
\end{aligned}
$$


The isolated position of this wonderful ore shoot, in a district of quartz-stibnite veins poor in gold and silver, is surely remarkable. The gold is strictly of primary origin, practically none of it having been dissolved and reprecipitated. The veins appear to belong to one and the same epoch of mineralization, the gold shoot being a local development upon one of the normal stibnite veins.

No entirely satisfactory explanation can be given of the causes leading to the abundant precipitation of gold in the National shoot. There is no reason to believe that the solutions depositing the vein here were radically different from those circulating elsewhere except in the large amount of gold and silver they contained. Surely it is difficult to account for such abnormal concentration by any theory of leaching by water from country rock. More likely this great quantity of the precious metals was set free locally at one point by deep magmatic processes and carried up in the thermal waters until a place favorable for precipitation was reached.

Probably the branching of the vein just north of the Stall shaft played an important part in this precipitation, for at this point solutions of different characters or of thermal waters and surface waters may have been mingled. As shown in figure 7 this junction of two branches takes place partly in the shoot, though the larger and richer part of the shoot lies just south of this junction.

Late movements. - There is ample evidence that movement has taken place along the footwall, and perhaps also along the hanging wall, after the deposition of the quartz. The brecciation of the latite between the walls may have been a primary feature, but in many places the quartz seam is broken along the footwall and some of the fragments are rolled and rounded. The movement took place so lately that the fractures it caused have not been cemented by quartz or calcite. Striations on the walls in general follow the dip of the vein.

Ore.-The prevailing gangue mineral is quartz; calcite is rarely seen except in the altered wall rock and adularia occurs only in small quartz stringers in the walls. The quartz was apparently deposited in open fissure as shown by the symmetrical structure of the stringers in the vein. (See fig. 6.) The quartz from the central part of the vein (see $d$ in fig. $4, c$ in fig. 6) is in general massive and very fine grained but contains small drusy cavities. Solution cavities coated with quartz crystals may occur in the wall rock. The stibnite veins of the district are generally more prominently vuggy and often show large cavities. No calcite, barite, or fluorite was found in the vein filling.

Sulphide minerals are very scant; small grains of pyrite, chalcopyrite, galena, and zinc blende occur at the base of the outer layer of radical quartz along the walls. In the medial fine-grained quartz of 


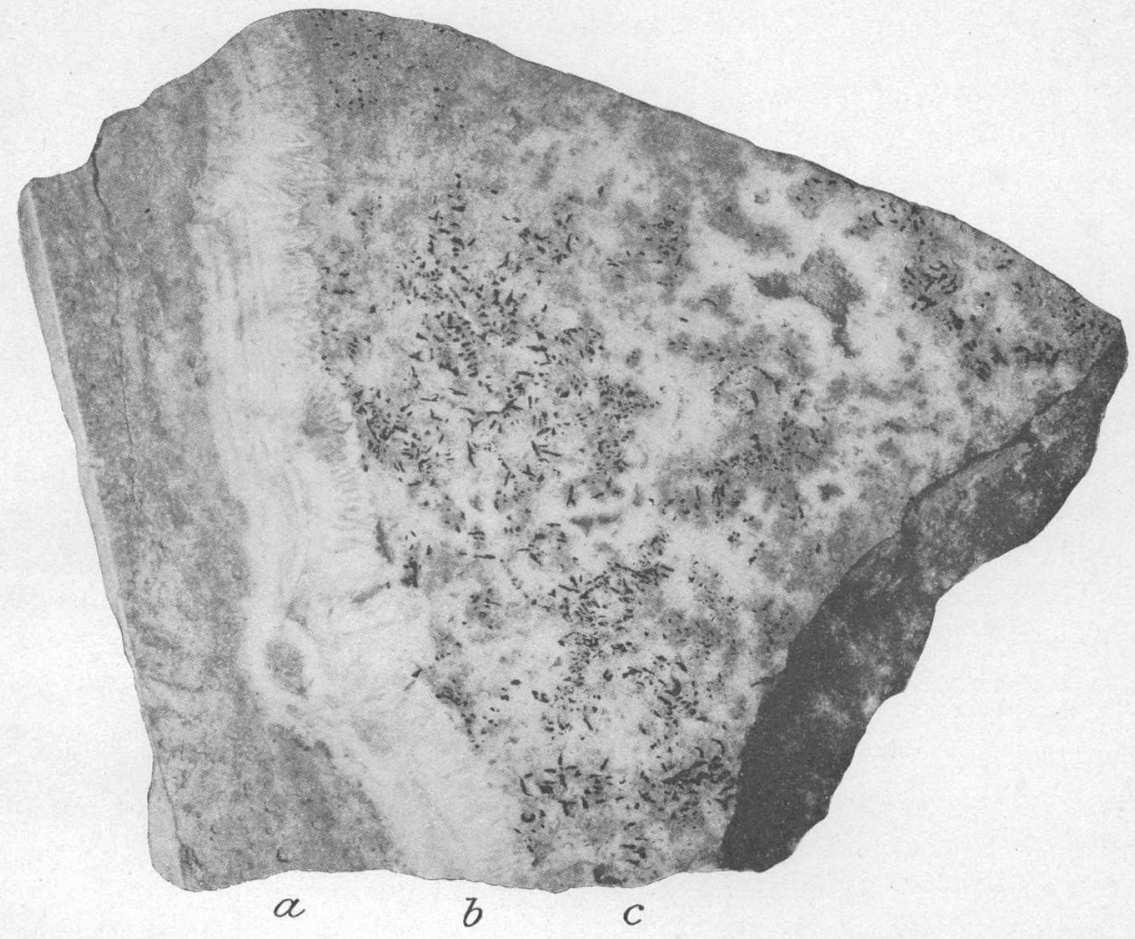

A. GOLD QUARTZ FROM NATIONAL MINE.

$a$, Altered country rock with little pyrite; $b$, white comb quartz (contains no gold); $c$, fine-grained quartz, vuggy in places, with abundant coarse gold showing dark gray. Magnified 2 diameters.

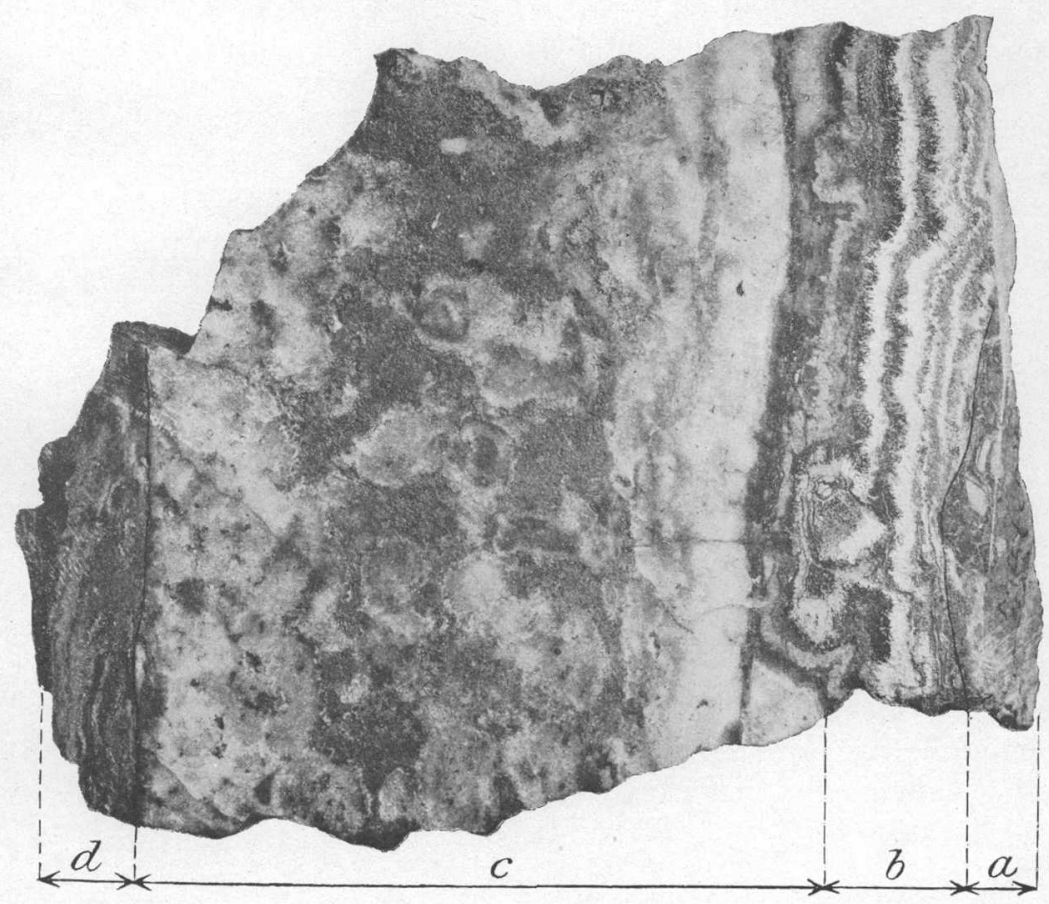

B. STIBNITE VEIN, RADIATOR HILL.

$a$, Brecciated wall rock separated by slip from vein; $b$, alternating bands of light and dark comb quartz and five bands of crustified stibnite (white); $c$, vein filling of gray quartz, crustified and drusy in center. Druses filled with yellow oxidation products of stibnite; $d$, brecciated stibnite crusts separated from quartz by slip. Natural size. 
the vein some stibnite is found, though it is by no means abundant. The yellow discoloration of the oxidized vein points to its general occurrence.

Small crystals and stringers of arsenopyrite were found in the altered rock on the dump of the mine, and according to otiner observers this mineral is not at all uncommon in the vein.

Gold is by far the most valuable metallic mineral in the shoot. It occurs as practically pure electrum, an alloy composed of about 50 per cent gold and 50 per cent silver, which is of a pale grayishyellow color and is therefore difficult to recognize in specimens.

It can not be positively stated whether there is any difference in the value of the gold in different parts of the shoot. According to some mining men consulted the gold near the surface was of paler color and worth only $\$ 9$ an ounce, whereas that found in depth had a value of $\$ 11$ an ounce.

The gold occurs almost exclusively in the fine-grained dull-white quartz in the center of the veinlets (fig. 4), where it is capriciously distributed, though where it occurs at all there is usually much of it. The quartz shows in places small vugs with projecting crystals, but the gold is in no way connected in its occurrence with these. Instead it is usually heaped in the massive and most fine-grained portions of the quartz and grows scarcer as it approaches these little cavities. A few small steel-gray specks of an undetermined mineral occur with the gold, but no mineral is intergrown with it.

Under the microscope the larger quartz crystals in the coarsely crystalline band along the walls have the peculiar "flamboyant" appearance between crossed nicols noted in similar quartz from Tertiary gold veins of Cripple Creek and San Juan region, Colorado. The border between the coarse and fine quartz is surprisingly sharp, but in some places the succession may be repeated, so that the finegrained quartz may contain veinlets of coarse and barren quartz. The fine-grained quartz (Pl. VI, $A ; \mathrm{Pl}$. VII) is usually an allotriomorphic aggregate of grains of various sizes, but each grain is well defined and few show interlocking texture. The quartz also contains shreds of sericite and calcite and small pieces of wholly silicified and sericitized country rock. Fluid inclusions are probably abundant in some cloudy parts of the quartz, but are so irregular and minute that they could not be identified with certainty.

The gold takes the form of elongated rodlike or clublike masses, each at the most 3 millimeters long; many T-shaped, divergent, or crossed bodies occur; the outlines are irregular or jagged, some of them suggesting crystal forms. On the whole there is a very distinct suggestion of dendritic growth, as if the forms were produced by crystallization in a yielding medium, possibly in a central mass of 
gelatinous silica which afterward slowly crystallized to a fine-grained aggregate. (See Pls. VII, $A$; VIII, $A$.)

Plate VIII, $B$, is a photograph of a thin section of ore, kindly lent by Mr. H. L. Hollis. In this plate the dendritic-development of the gold is very striking; the gold shows no tendency to follow fissure cracks in the quartz and its primary nature is beyond doubt.

The only explanation which seems to be satisfactory is that the gold and the quartz crystallized together from the same solution, and it is most likely that these solutions contained gold and silver in the form of alkaline sulphides.

In order to ascertain the distribution of the gold a number of assays were made by Prof. E. E. Bugbee, of the Massachusetts Institute of Technology, of the footwall quartz seam in which the high-grade ore ordinarily occurs. Two assays were made of quartz found near the top of a 150-foot raise in the fifth tunnel, near high grade. The two assays gave a trace of gold and less than an ounce of silver per ton.

Another assay was made of the typical quartz seam, of which a diagram is given in figure 6 . The sample was taken by the writer in very rich stopes in level No. $4 \frac{1}{2}$, only a foot or two from quartz containing much free gold. Chips were taken from all sides of the specimen, which formed a complete cross section of the 4-inch vein. The assay showed only a trace of gold and less than an ounce of silver to the ton.

These results go far to confirm the statement of the mine officers that there was practically no second-class ore or milling ore in the rich shoot.

Oxidation.-It has already been stated that the water level at the Stall shaft stood high, only 40 feet below the surface. The outcrops of the vein are shown at only one point, near the shaft just mentioned. Some oxidized ore rich in silver was found here, and near the top of the gold shoot ore with much ruby silver was taken out. The stibnite in the vein is oxidized to yellow earthy material in the uppermost level and in places also through the lower levels. It is possible that some of this oxidation has taken place since the vein was opened and drained. It is reported by Mr. H. V. Winchell that considerable amounts of realgar and orpiment were found south of the ore shoot in a part of level No. 2, which was not opened in 1911. N. A. Winchell also states that native arsenic was found at several places. All three of these minerals have probably been formed by the oxidation of arsenopyrite.

Secondary sulphides.-As stated above, there is but little primary pyrite in the ore, and in fact primary sulphides of all kinds are scarce. Marcasite is, however, abundant and occurs throughout the vein in and out of the rich shoot, but always as coatings, crystallized or mammillary, on the joints and fissures in the quartz, or is dusted on 


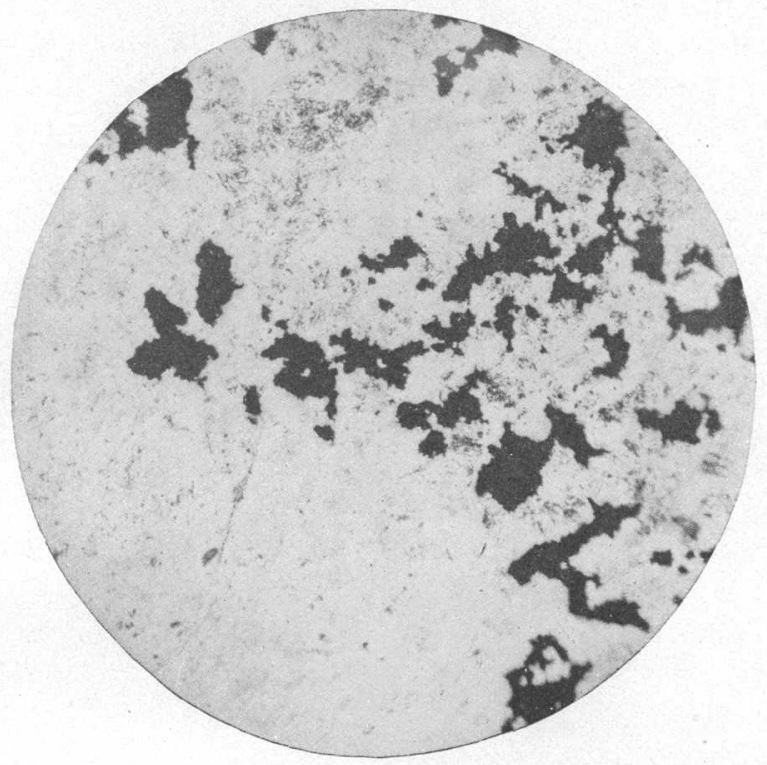

A. Parallel nicols; magnified 60 diameters.

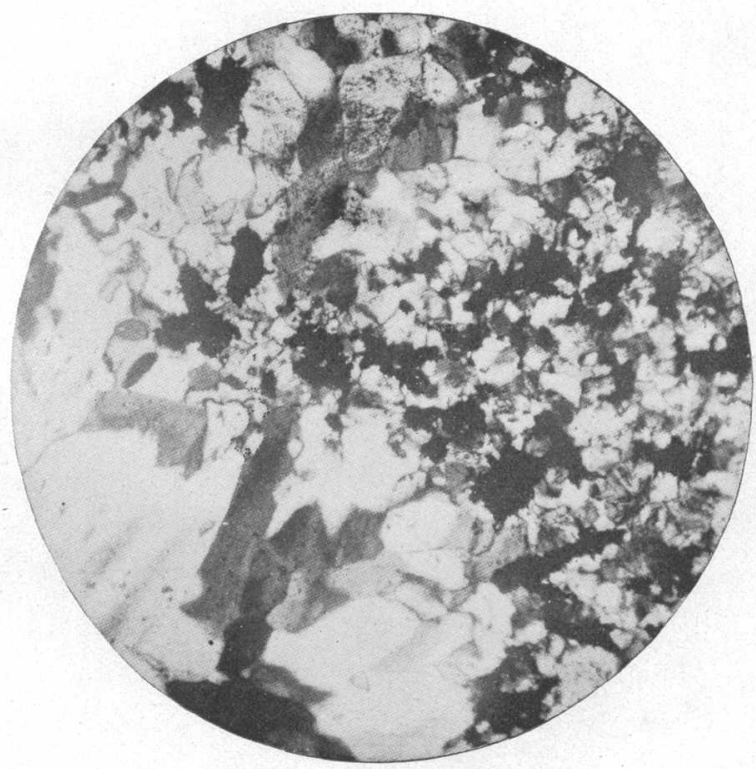

$B$. Crossed nicols; magnlfied 60 diameters.

THIN SECTIONS OF GOLD QUARTZ FROM NATIONAL MINE. 
the pyramids of quartz crystals in small druses. Scarcely a specimen of quartz or vein matter is without this secondary sulphide.

On the joint planes of the quartz in the rich shoot there is also more or less pyrargyrite, or antimonial ruby silver. In places there are also flat bunches of stibnite needles. In the ore of the Chefoo tunnel (p. 47) secondary stibnite was found as capillary coatings in little quartz vugs. As far as could be ascertained by the inspection of a large quantity of high-grade ore no recrystallization of the gold had taken place. In a few places, however, it was noted that the gold cut by joint planes was of a deeper yellow color than ordinarily, which would indicate that some silver had been leached from the electrum.

The secondary sulphides, then, comprise marcasite, pyrargyrite, and stibnite, and also realgar and orpiment. No gangue minerals appear to have formed simultaneously with these sulphides. It is concluded that these sulphides were deposited from cool solutions long after the vein had been formed. Whether these solutions were descending or ascending can not be positively stated, but the presence of much marcasite, taken in connection with the scarcity of primary pyrite, might indicate deposition by weak ascending solutions.

According to E. T. Allen ${ }^{1}$ marcasite is always deposited by acid solutions. Whether the solutions that formed the marcasite in the National vein were acid or not may be left an open question; if they were acid they were descending, but they must have been weakly acidic, because the primary vein contains so little pyrite.

Observations made by the writer at the El Oro mines of Mexico seem to show that marcasite may be deposited by neutral and weak calcium carbonate solutions having a temperature of about $35^{\circ} \mathrm{C}$; and here also the deposition is distinctly a later phase than the vein formation proper.

\section{NATIONAL MAMMOTH MINING CO.}

Three tunnels have been driven by the National Mammoth Mining Co.onear the property lines of the National Mines Co.

Tunnel No. 1 (elevation, 6,672 feet) enters rhyolite. About 58 feet from the portal, on the contact with basalt, lies a small vein which in 1911 had not been traced further. This is practically on the level of the collar of the Stall shaft.

Tunnel No. 2 (elevation, 6,499 feet) follows nearly the line between West Virginia claim and West Virginia claim No. 1. The portal of this tunnel is in rhyolite, and 100 feet from the portal the tunnel cuts into latite. About 600 feet from the portal a vein was cut

' Allen, E. T., Crenshaw, J. L., and Johnston, John, 'The mineral sulphides of iron: Am. Jour. Sci., 4th ser., vol. 33, pp. 169-236, March, 1912. 
which the company considered to be the southern continuation of the National vein. Basalt lies in the footwall, and the vein when entering this rock splits into several seams. The vein strikes N. $7^{\circ}$ E., dips $70^{\circ}$ W., is 3 feet wide, and consists of a clay gouge with broken quartz seams. Excellent ore, said to assay $\$ 100$ in silver and $\$ 2$ to $\$ 3$ in gold, was found in this vein and small shipments were made.

Tunnel No. 3 (elevation, 6,300 feet) was 500 feet long in June, 1911, and is entirely in rhyolite. Toward the face the rock is pyritic and contains quartz seams.

\section{RADIATOR HILL.}

At least one quartz vein intersects Radiator Hill. The first developments were noted in a 40 -foot shaft 600 feet northwest of the gap leading over to Threemile Creek. A quartz vein exposed here strikes N. $10^{\circ} \mathrm{W}$. and stands vertical. The vein consists of seams of comb quartz lined at the walls by radial stibnite (Pl. IV, $B$ ) and contains small specks of tetrahedrite. It intersects a whitish de posed rock, probably a rhyolite. The ore is oxidized at the su ace fresh stibnite is found at a depth of a few feet.

This vein could be followed on the surface for about 309 feet iw the direction of the strike. An assay of a piece of selected quartz $v$ stibnite gave a trace of gold and 12 ounces of silver to the ton.

A tunnel started on the north side of Radiator Hill, close to the National Hotel and at the same elevation, intersected the vein described above. Some ore, containing chiefly silver with considerable antimony, is said to have been shipped. Unfortunately the tunnel was inaccessible during the writer's stay at National. Evidently no shoots of any considerable value had been found.

Somewhat farther east of and below this vein another deposit, perhaps 15 feet wide, showing some stains of antimony, had been discovered in 1911. The exposures were poor. Selected ore from this deposit was said to have given assays of $\$ 14$ in gold and 12 ounces of silver to the ton.

\section{ROUND HILL.}

Some prospect tunnels have been driven at places on the slopes a short distance north of the National Hotel. A tunnel on the Friction claim, 130 feet above the hotel, shows decomposed tuff containing irregular veinlets of quartz and small cavities filled with crystals of quartz and marcasite.

The principal developments are, however, on the Chefoo claim. The crosscut tunnel trends N. $55^{\circ} \mathrm{W}$. and encounters a vein at 416 feet. On this vein drifts have been extended 45 feet south and 20 feet north. The tunnel is driven wholly in decomposed basalt thas includes some harder residual bowlders which show that the basalt contained phenocrysts of triclinic feldspar. 


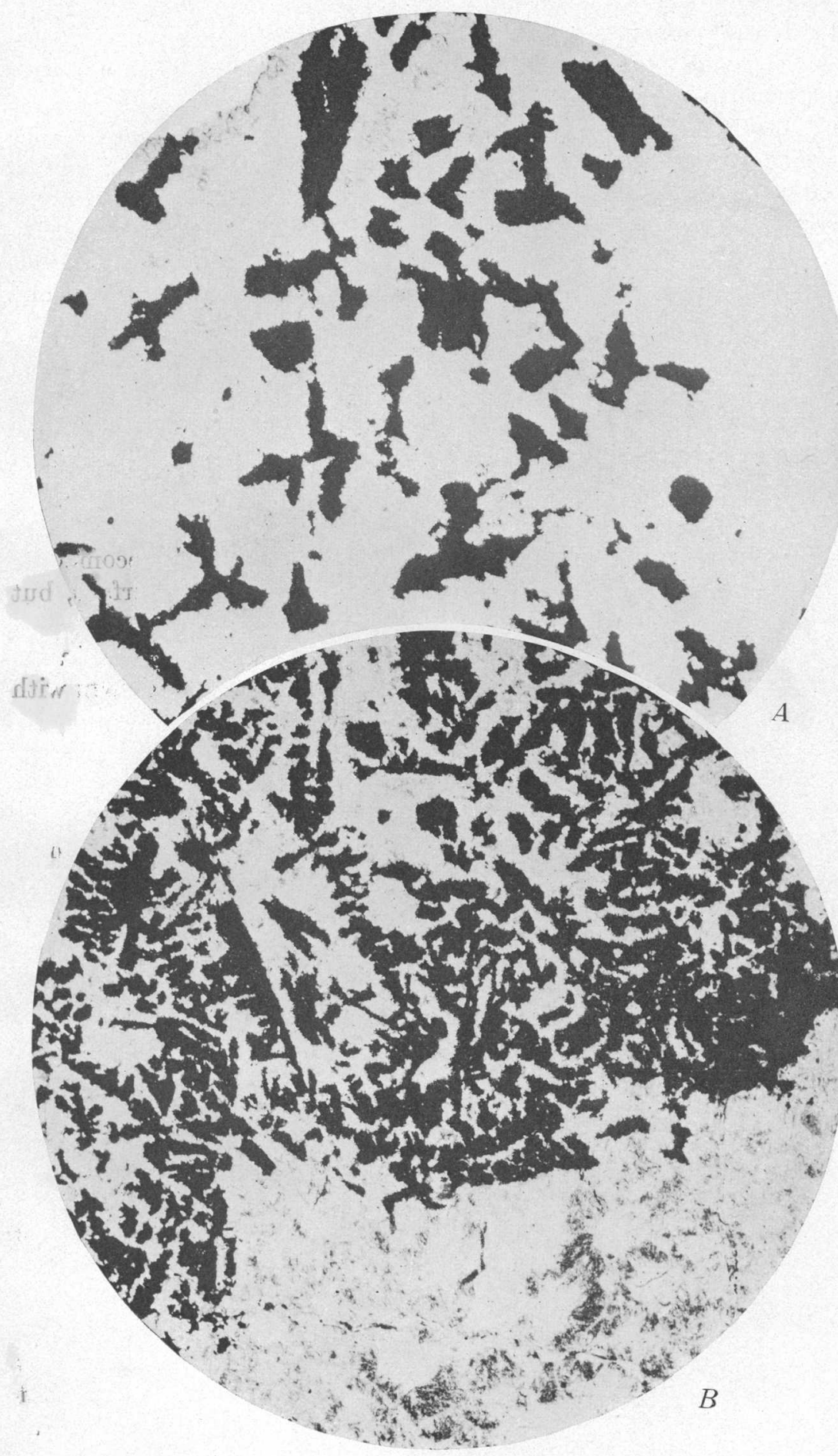

PHOTOMICROGRAPHS OF GOLD QUARTZ FROM NATIONAL MINE.

Black areas are gold. $A$, magnified 30 diameters: $B$, magnified 29 diameters. 
The rock exposed in the footwall in the south drift is a basalt but is greatly altered by the development of sericite, calcite, and pyrite. The hanging wall is still more strongly sericitized. Adjoining the unaltered footwall is a vein 3 feet wide of soft white rock containing several clay partings; next follows a seam of clay, which widens to a 4 or 5 inch vein of silicified and pyritic material, made up of fragments of country rock, and containing also small crystals of arsenópyrite, and between these fragments are crusts of fine quartz crystals resting upon narrow bands of pyrite, zinc blende, and chalcopyrite. In the vugs delicate capillary needles of stibnite rest upon the quartz crystals. This stibnite and some marcasite are the latest minerals formed. The hanging wall consists of soft white rock, which gradually gets harder with increase of distance from the vein. Assays of specimens of good-looking ore from this locality gave 20 cents in gold and 16 ounces of silver to the ton. Some ore obtained here is sajd to have contained tetrahedrite and is reported to have contained $\$ 40$ in gold and $\$ 625$ in silver to the ton. None has been shipped, and the vein is probably too narrow for exploitation.

\section{AUTO HILL.}

In the gap at the west base of the Auto Hill, about 600 feet above the hotel, are several interesting developments.

A rhyolite dike about 50 feet wide, which first appears in the upper end of the town and can be traced up to the gap just west of the Auto Hill, shows decided evidences of mineralization. It is dislocated by several small faults.

Rich oxidized ore with quartz seams was found on the ground of the Walker lease 100 feet south of the gap. Some of it is reported to have contained 2,500 ounces silver and 3 ounces of gold. The ore is said to have contained stibnite, bismuth (?), cinnabar, native silver, and ruby silver, with much yellow antimony oxide. There is also a little chalcopyrite and covellite. Some ore, probably not over 5 tons, was shipped from here. It was rich in silver but contained only $\$ 1$ or $\$ 2$ in gold to the ton. These workings are not accessible now and no certain conclusions as to the character of the deposit could be drawn from exposures at the surface.

\section{BLUM SHAFT.}

Deeper developments were undertaken in the Blum shaft, which is vertical and is 260 feet deep. . Its collar has an elevation of 6,630 feet. This shaft is apparently sunk in the rhyolite dike. The rock is a soft earthy rhyolite with sparse crystals of pyrite. Under the microscope it shows corroded crystals of quartz and a few of sanidine in a groundmass of microgranular quartz and orthoclase. The rock contains much sericite and kaolin. The vein is narrow but well defined, strikes N. $8^{\circ} \mathrm{E}$. and dips $70^{\circ} \mathrm{W}$. It consists of clay gouge with several quartz 79102 ${ }^{\circ}$ Bull. $601-15-1$ 
stringers 8 to 10 inches wide. Much of the soft stuff on the dump contains cinnabar, shown by panning. Cinnabar was found at a depth of 30 feet, and more abundantly in solid streaks 1 inch to 2 inches wide at a depth of 60 feet.

At the 100-foot level in the Auto shaft the vein was found in a short crosscut, run eastward, but was here pinched and oxidized.

On the second level, 160 feet below the surface, where water now stands, crustified quartz seams were observed, showing pyrite, galena, zinc blende, and slight stains of copper. On the lowest level the vein is said to have been very narrow. No ore was shipped from the shaft.

\section{EDMUNDS TUNNEL.}

The Edmunds tunnel is 100 feet below the National tunnel No. 5 on the west side of the gulch. Its course is N. $22^{\circ}$ W. and its total length is 485 feet. At a point 320 feet from the portal a shaft was sunk to a depth of 130 feet. It was full of water at the time of visit. The country rock is basalt, but 370 feet from the portal the rhyolite dike, outcropping above, was encountered.

At the shaft a quartz seam 2 inches wide was cut, which continued down into the shaft. Operations were stopped by the sudden influx of water.

\section{CRAWFORD TUNNEL.}

The Crawford tunnel is close to the Edmunds tunnel and 40 feet above it. It extends 300 feet in a northwesterly direction. It encountered a small vein, which was followed by drift and shaft, the shaft extending 70 feet below tunnel level. Farther in the tunnel another vein was struck which, like the first, contained quartz and calcite. The two veins are 20 feet apart.

\section{HATCH TUNNEL.}

The Morning Star or Hatch tunnel, operated in 1911 by the proprietor of the National Hotel, is on the west side of National Gulch at an elevation of 5,970 feet, 130 feet vertically below the office of the National Mines Co. The tunnel was started to intercept the National vein on the supposition that the vein was faulted across the gulch. The portal of the tunnel and the first 200 feet are in rhyolite; next follows a clayey, tuffaceous rock, probably basalt tuff, which is brecciated in places and contains more or less pyrite. Some shaly and coaly material was also found. The tunnel was 900 feetlong in 1911, and near the face encountered soft and whitish basaltic rock. No veins had been found, although some of the pyritic material gave assays of gold and silver amounting to $\$ 1$ or $\$ 2$ to the ton.

\section{HYDE TUNNEL.}

In the Hyde tunnel No. 2, about 360 feet northeast of the lowest adit of the National mine and 40 feet below it, a vein was cut 200 feet from the portal, which probably is one of the stibnite veins lying a 
short distance west of the principal National vein. It was drifted on for about 300 feet, but failed to yield ore. Near the portal a shaft was sunk to a depth of 82 feet, and in this probably the same stringer was cut. The quartz sparingly present along the vuggy vein yielded some stibnite and a few flakes of visible gold. Some ruby silver was also found near the surface. The country rock is latite, considerably kaolinized, and traversed by a network of pyrite stringers.

\section{DEVELOPMENTS SOUTH OF STALL SHAFT.}

Considerable effort has been made to locate the extension of the National vein south of the Stall shaft, on that part of the ridge which slopes toward Charleston Gulch.

A few hundred feet south of the Stall shaft is the shaft sunk by Caustin and Jarvis to a depth of at least 180 feet as an incline sloping $50^{\circ} \mathrm{W}$. A vein with some quartz was said to have been cut, but presumably no ore was found, for the operations were long ago suspended. (See Postscript, pp. 52-55.)

The Bankers' shaft is 225 feet farther south, and about the same distance south of this is the Diffenbach Defiance shaft. The Bankers' shaft is about 300 feet deep. A short crosscut was driven from this level and is said to have cut a vein. The shaft is an incline, dipping $60^{\circ} \mathrm{W}$. The Diffenbach shaft is vertical and of about the same depth. Altered rock containing some marcasite was found at both places. The rock appears originally to have been a basalt, and a heavy body of fresher basalt lies immediately, west of the three shafts.

A few hundred feet farther south a vein showing stibnite and some "silver sulphides" is said to have been opened on the property known as McDonald's lease. In the court trial referred to (see pp. 52-54) evidence was adduced that seemed to prove that the National vein passes through the Caustin shaft, the Bankers shaft, and McDonald's tunnel.

\section{INDIAN VALLEY TUNNEL.}

About 1,200 feet east of the National vein some prospecting has been undertaken on the Indian Valley claim. A tunnel has been driven 500 feet south, on a vein which contains much stibnite in spots. The vein is in places 5 feet wide and consists mainly of altered rhyolite, with some quartz stringers. The vein has a steep dip and strikes N. $8^{\circ} \mathrm{E}$. A specimen of the ore shows well-crystallized stibnite, cementing the fragments of a rhyolite breccia which contains finely divided pyrite. No minerals were observed with the stibnite except a little kaolin. Picked specimens of stibnite contain only a trace of gold and less than 1 ounce of silver to the ton. 
A crosscut to the east 365 feet from the portal meets basalt 90 feet from the stibnite vein and the basalt contains near the contact several seams of quartz with pyrite, stibnite, and calcite. This basalt is a part of the succession of flows which begins immediately east of the rhyolite dikes at the Indian Valley mine.

\section{PROSPECTS ON BUCKSEIN PEAK.}

Topography.-The trail to Buckskin Peak goes up Charleston Gulch to the divide and then skirts the high ridges at the head of the cirque of Threemile Creek. It is an easy trail, by which the mountain can be comfortably ascended on horseback.

The elevation at the head of Charleston Gulch is about 7,500 feet, and the top of Buckskin Peak 8,800 feet. The ridges are practically bare and are free from snow about August 1 . In places in the gulches there are small groves of fir trees.

Geology. - The trail ascends the basalt flows of Charleston Gulch and at the divide passes a plug or neck of rhyolite and obsidian. For a mile the trail then continues southeastward over basalt or similar rocks. Fine views open to the west and east, and as far as can be seen the basalt flows descend down on the east side of the range; in fact, on that side nothing but basalt is in view.

About a mile southeast of the head of Charleston Gulch, at an elevation of 8,300 feet, the trail enters the rhyolite area of Buckskin Peak. The rhyolite is fine grained, felsitic, and light colored and breaks up in sherdy fragments.

On the top of Buckskin Peak there are undoubted evidences of hotspring action. The rhyolite is silicified and chalcedonic and weathers into irregular rough outcrops.

The rhyolite area of Buckskin Peak is clearly a flow which, as shown on the spur south of Threemile Creek, is underlain by basalt flows, and which, likewise, as shown on the trail to the summit, is covered by basalt. The greatest thickness of this flow is about 1,200 feet. It was probably viscous and its thickness would not be maintained for long distance from its feeders. There is no doubt that the numerous rhyolite dikes of the National district belong to the same epoch of eruption, which would fall in the later part of the period of the basaltic flows.

Veins and prospects.-The veins on Buckskin Peak are said to have been known and located long before the rich bonanza of the National district was discovered. They are near the divide, on the east slope of the main ridge just north of the peak.

The Bell \& Ward prospect is situated at an elevation of 7,950 feet, the main peak bearing S. $70^{\circ} \mathrm{W}$. This is the most southerly location. The developments consist of three short tunnels. The vein, which is in rhyolite, strikes north and south, and the ore consists of a 
fine-grained, almost chalcedonic quartz, which probably replaces rhyolite. Bunches of stibnite needles and grains of pyrite replace this chalcedony or less silicified rhyolite. The ore is said to carry silver.

The Neversweat claim is half a mile north of Bell \& Ward's, but the vein is said to lie 600 feet east of that in the latter property.

A shaft 80 feet deep has been sunk on a narrow vein striking north and dipping steeply west. Some drifting had been done. The ore is said to contain some gold, but its value lies principally in silver. Many assays of $\$ 30$ to $\$ 100$ are said to have been obtained.

The vein contains 5 to 10 inches of quartz filling, in places apparently pseudomorphic after calcite. Some adularia is mixed with the quartz, and pyrite was observed in the specimens. Ruby silver, cerargyrite, and native silver are said to occur in the ore, but there seems to be no stibnite. Two check assays were made of quartz from the Neversweat shaft; the first yielded 40 cents in gold and 21 ounces of silver, the second $\$ 1.40$ in gold and 105 ounces of silver to the ton.

A little north of Neversweat prospect is the Martin property, but this was not visited.

In part, at least, there is some similarity between the veins of Buckskin Peak and those at National. They are mainly silver veins and at least one of them contains stibnite. The strike is north in both districts.

Summit of Buckskin Peak.-As stated above, the rhyolite summit of Buckskin Peak has been irregularly altered by hot-spring solutions. The outcrops are craggy and consist in part of silicified rhyolite of light-gray color, in part of gray chalcedony, which is pitted, irregular, and rusty.

It is stated that those hot-spring deposits contain traces of gold and silver, as well as quicksilver. No trace could be found of cinnabar in the specimens examined. They contained, however, some small reddish-brown spots, which gave distinct reaction for selenium; probably occurring native as a result of oxidation. Too little material was available to ascertain with what metal the selenium was originally combined.

There can be no doubt that the hot-spring action which produced this chalcedonic material took place at the surface shortly after the eruption of the rhyolite and in the short interval which elapsed before the rhyolite again was covered by later basalt flows. 


\section{POSTSCRIPT.}

\section{APEX LITIGATION.}

In 1911, after the field examination of the National district for the United States Geological Survey was completed, the National Mines Co. brought suit against the Charleston Hill National Mining Syndicate and the Mammoth Mines Co., alleging trespass. This suit was tried at Carson City, Nev., in June and July, 1912, in the United States circuit court before Judge E. S. Farrington. During this trial a great deal of geologic testimony was introduced bearing upon the course and alleged faulting of the veins worked by the National Mines Co., and the testimony being public property it becomes necessary, for the completeness of this report, to refer briefly to the various points involved. Several geologists testified on each side, the principal witness for the National Mines Co. being Mr. Horace V. Winchell and for the defendants Prof. A. C. Lawson.

The apex of the National vein, which contains the great gold shoot described on page 32 , is within the West Virginia claim. The vein dips about $55^{\circ} \mathrm{W}$. and was followed downward until it crossed the west side line of the West Virginia and entered the adjoining claim of West Virginia No. 1, which belonged to the defendants.

The complainant asserted that the apex of this valuable vein crossed both end lines of the West Virginia claim, and that therefore extralateral rights existed, which conferred the privilege of following the vein on the dip outside of the side lines of the claim in which the vein apexed.

On the other side, the defendants, who had been driving the Mammoth tunnels Nos. 1, 2, and 3 (see Pl. V, p. 32) close to the side line separating the West Virginia from the West Virginia claim No. 1, claimed that only a part of the National vein existed in the West Virginia claim; that where a certain bend or turn (shown on Pl. V) exists on levels Nos. $1,2,3,3 \frac{1}{2}$, and 4 the National vein had been cut off by an important fault fissure, trending about N. $25^{\circ} \mathrm{W}$., which was traced from the gap at the head of Charleston Gulch by the McDonald tunnel, the Caustin shaft, and the levels driven in the mine workings south of the above-mentioned turn or bend; that the latter turn or bend, in fact, represented places where the later fault fissure intersected the older gold-bearing vein, and that therefore the apex of the National vein did not reach the southern end line of the claim, but that this southern part of the vein was thrown an unknown distance to the northward, and that consequently the National Mines Co. had no extralateral rights as far as the National vein was concerned.

The transcribed testimony occupies about 2,700 typewritten pages.

Mr. H. V. Winchell and other engineers and geologists of the complainant testified that the fissure was continuous through the several 
drifts to their ends; that there was no intersection south of the bend or curve where the strike changes from north to N. $25^{\circ} \mathrm{W}$. It was shown that the vein had the same width and character throughout, with similar mineralization and stringers of quartz, carrying near the bend abundant gold in places, and silver minerals, stibnite, pyrite, and arsenic minerals not infrequently throughout. Mr. Winchell stated (p. 2040 of transcript) that he had reached the conclusion that the National vein is continuous throughout, without interruptions, as far as developed, from the north end line of the West Virginia south through the workings; that it is joined by several fissures or branches going out from it into the hanging wall; but that it is nowhere severed or faulted.

This vein was traced south on the surface by several cuts or shafts to the Caustin shaft, now caved. (See Pl. V.) Mr. R. S. Bolam testified (p. 578 of transcript) that this shaft was sunk in the hanging wall, an open pit having disclosed the vein 10 feet east of the shaft; that the vein entered the shaft 35 feet below the surface and followed it more or less closely to the bottom (the depth is about 180 feet on the incline); that the vein was drifted upon for 40 feet south and proved 3 to 4 feet wide with two streaks of quartz, each 3 to 4 inches wide, one in the footwall and the other in the center of the vein; that the quartz contained antimony (stibnite), pyrite, and "sulphide of silver"; and that in a short drift north on the same vein, where the quartz was wider, 10 sacks of material were saved for ore. It was also testified that a vein, probably the same, was encountered in the Bankers shaft, 225 feet north of the West Virginia end line; in two smaller shafts close to the mentioned end line; and on McDonald's lease 600 feet south-southeast of the same end line.

For the Charleston Hill National Mining Syndicate it was asserted by several geologic experts that what the complainant regarded as the southern continuation of the National fissure was really a later fault with a slightly flatter $\operatorname{dip}$ (about $45^{\circ}-50^{\circ}$, against $56^{\circ}$ ); that while the fault fissure had a width similar to that of the National vein it had much more clay gouge and contained very little quartz and that of a drusy or comb character, while that in the vein was more massive. Further, that the striations in the wall in the fault were inclined slightly northward, and those in the vein were variously placed, some inclining steeply to the south, others being flatter. It was not denied that some mineralization had taken place along this fault fissure but it was of a different kind, and it was attempted to prove by assays that south of the intersection the fissure carried more silver in proportion than the vein. It was testified by Mr. Fred. Searles, jr. (p. 2532 of transcript), that the prevailing rock near the National vein is a rhyolite, a rhyolitic felsite, or a rhyolitic tuff (see pp. 28-29 of this bulletin), but that the rock in the hanging wall of the fault fissure is of basic 
nature and different from the rock either in the footwall of the fault or in the hanging wall and footwall of the vein. He therefore concluded that the fault itself represented a boundary for a large block of basic rock which contrasts with the acidic rork in the footwall of the faultall this confirming the existence of a fault of considerable throw.

Naturally the conditions at the crucial points at the bend of the veins on the various levels were carefully and thoroughly discussed. The defense proved to its satisfaction that the vein was obliquely intersected and the complainant introduced seemingly equally good testimony proving that the vein was continuous with the fault and that a small branch only extended from the bend into the hanging.

It was admitted that the last well-defined exposure of the vein or the fault fissure toward the south was found in the tunnel on the socalled McDonald lease. Prof. Lawson stated that south of this tunnel (see Pls. I and V) the fault fissure entered a younger volcanic series, consisting of basalt and rhyolite, and that 3,000 feet from the same tunnel, at the gap at the head of Charleston Gulch, there was direct and positive evidence of a fault having a vertical throw of 600 feet. Though he admitted that the fault fissure itself was not exposed he showed that there existed immediately west of the gap a flow of obsidian and rhyolite ${ }^{1}$ overlying basalt and that another part of the same area was found on a hill 1,200 feet east of the gap, at a considerably higher elevation. It was thought that the throw of 600 feet shown here also represented the approximate throw at the intersection of the vein and the fault fissure.

The decision of the court ${ }^{2}$ was rendered after a personal visit to the district. It is a remarkable document, showing keen logic and great geologic ability. After acknowledging the high character and the sincerity of the experts Judge Farrington stated that although there were some differences of minor importance between the National vein north of the bend and the portion south of the bend there were no greater differences than are usually found from point to point along the course of veins, and that the portion of the vein north of the bend was one and the same vein as the portion south of the bend.

The decision ends with the following words:

I am unable to. discover wherein the National vein in No. 4 level and in Mammoth No. 3 tunnel east, south of the break, differs materially from the so-called fault fissure either as to strike, dip; or mineralization. I therefore find that the fault and the vein are parts of one and the same fissure. The distinctions which have been called to my attention are due to causes, forces, and conditions which have been present at one end of this fissure but not at the other, or which have differed in efficiency as they were applied north or south of the bend.

1 This rhyolite is here (p. 29) interpreted as an intrusive mass, not as a flow.

2 The Federal Reporter, vol. 205, pp. 787-800, St. Paul, 1913. 


\section{COMMENTS ON STATEMENTS EIICITED BY THE SUIT.}

The present writer last visited the mine in 1911 and has therefore not seen many of the openings made later for the purposes of the trial. The levels, which were inspected at the bend, did not seem to present any evidence of intersection by a fault fissure. The evidence of the existence of stopes containing gold south of the bend seems good and, according to the evidence of the defendants, this ore can not well have been carried in as drag. There does not seem to be any strong or definite evidence of two epochs of mineralization at National. Apparently the whole mineralization can be traced to the latest eruption of the rhyolite of Buckskin Peak. The evidence of faulting along the "fault fissure" presented by Mr. Searles is not conclusive, for close to the fissure it is often impossible to recognize the various rocks, and no distinction seems to have been drawn between the latite and the rhyolite. There is probably a considerable postmineral displacement along the National vein which is quite competent to bring basalt against intrusive rhyolite or against latite in the southern part of the vein.

Finally, the fault fissure has not, as far as known, been traced, on the surface or underground, north of the alleged intersection.

Another line of evidence tends in the same direction. The National vein splits north of Stall shaft and the ore follows the eastern branch for a short distance, though the bulk of the ore shoot lies south of the junction. The western branch of the vein is intersected by the crosscut tunnel No. 5 about 400 feet from the portal, and proves to be a fissure with approximately the same dip as the main vein and to be filled with vuggy quartz containing much stibnite. It carries very little gold and silver and is apparently mineralogically similar to the "fault fissure," though narrower and containing less gouge.

On the whole, it seems certain that there is only one vein and that the National vein and the fault fissure are one and the same thing. These conclusions are supported by the mine maps showing the developments up to 1914 . In levels Nos. 4, 5, 6, and 7 there is no such decided turn as in the upper levels, but a gradual curving from a northerly strike to one of N. $25^{\circ} \mathrm{W}$. 



\section{INDEX.}

A.

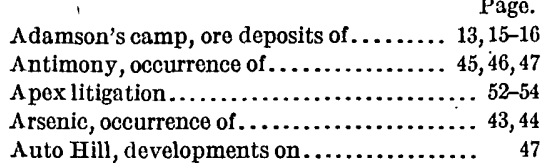

B.

Bankers' shaft, description of.............. 49

Basalt, distribution and character of........ 23-24

flows of, plate showing............... 22

Bell \& Ward prospect, description of........ 50-51

Bloody Run Peak, elevation of............ 8

Blum shaft, vein followed by............. 47-48

Bolam, R. S., acknowledgment to.......... 13

Buckskin Peak, elevation of............ 10, 19, 50 geology of ......................... 50

ore deposits on ...................... 14

plate showing......................... 18

prospects on........................ 50-51

topography of ..................... 50

Bullion mine, production of .............. 16

Bullion-Wildgoose vein. See Spring City camp.

C.

Canyon Creek, ore deposits on.............. 14

Caustin and Jarvis shaft, description of...... 49

Charleston Hill, plate showing............. 30

Charleston Hill National Mining Syndicate, suit against................. 52-54

Cinnabar, occurrence of............ 14, 15,47,48

Climate of the Santa Rosa Range........... 10

Crawford tunnel, description of............. 48

D.

Development of the district............... 19-21

Diffenbach Defiance shaft, description of.... $\quad 49$

Drainage of the Santa Rosa Range.......... 10

\section{E.}

Edmunds tunnel, description of........... 48 Electrum, occurrence of . ..... 14, 31, 32, 38- $39,40,43$

\section{F.}

Farrington, Judge E. S., decision of

Fossils, occurrence of..

G.

Genesis of ores. 32-33

Geology of the district.... 21-22, Pl. I (in pocket) of the Santa Rosa Range............... 10-12

Gold, mode of occurrence of ............. 12-13, $14,15-16,30-31,32,38-44$ production of............... 16-17,19-20,32 relation of, to silver. See Electrum.

Gold quartz from National mine, plates showing $42,44,46$
H.

Hatch tunnel, description of................ Page.

Hyde tunnel, description of .............. 48-49

I.

Indian Valley tunnel, description of ........ $49-50$

L.

Latite, distribution and character of........ 24-27

Location and general features of the district... 7,18

M.

McDonald's lease, vein cut on ............ 49

Mammoth Mines Co., suit against......... 52-54

Mineral deposits of the Santa Rosa Range... 12-16

Morning Star tunnel, description of......... 48

N.

National, Nev., general view of.

National Mammoth Mining Co., development by ......................... $45-46$

National mine, alteration of country rock in.. 36

development and equipment of......... 33-35

geology of ............................ 35

gold shoot of....................... 32

lato movements in................... 42

map of............................. 32

metal production of .................. 17

minerals in........................... 42

ore shoot of........................ $38-44$

oxidation in ........................ 44

plate showing ....................... 30

secondary sulphides in.............. 44-45

vein of .................... 36-38, 52-54,55

rocks from....................... 26-27

National Mines Co., suit of . ............ 20, 52-54

Nevada mining districts, publications on.... 5

Neversweat claim, description of .......... 51

o.

Ore deposits of the district, general character of............................. 30-31

P.

Paradise Valley Mining Co., production of.... 16-17

Paradise vein. See Spring City camp.

Placers on Willow Creek.................. 14

Pole Creek, ore deposits on................. 14

Pride of the Mountain mine, ore deposits of... 13 production of........................ 16

Prospecting in the district.............. 19-20

R.

Radiator Hill, developments on........... 46

Ransome, F. L., preface by................ 5 5-6

Rebel Creek, ore deposits on.............. 14,17

Rhyolite, distribution and character of ..... 28-29 


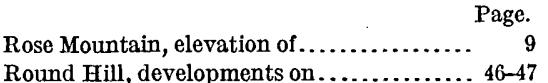
rocks from

\section{S.}

Santa Rosa Range, description of literature of. metal production of west slope of, plate showing

Silver, mode of occurrence of

production of.

$14,30-31,32 ; 38-44$

Solutions, ore-forming, similar to waters of hot springs

Spring City camp, ore deposits of ...... 12-13, 13-14 Spring Peak, elevation of.

Stall Brothers, discovery by .............. 38-39

Stall shaft, view from.

Stealing of ore.

Stibnite, absence of, in bonanza ore shoot...
Stibnite, occurrence of ...... 14,30-31,43,49,51 from Radiator Hill, plate showing specimen of . . .

T.

Topography of the Santa Rosa Range..... . 7-10

Trachyte, distribution and character of..... 27-28

Value of ores in the district. . . . . 20,21,32,39-40

Vegetation of the Santa Rosa Range........ 10

Veins, genesis of. ................. 32-33

W.

Willow Creek, ore deposits on .......... 14,17

Winnemucca Mountain, elevation of........ 8

Workman, J. L., discovery by........... 19

Z.

Zinc blende, occurrence of ............. 13,48 